
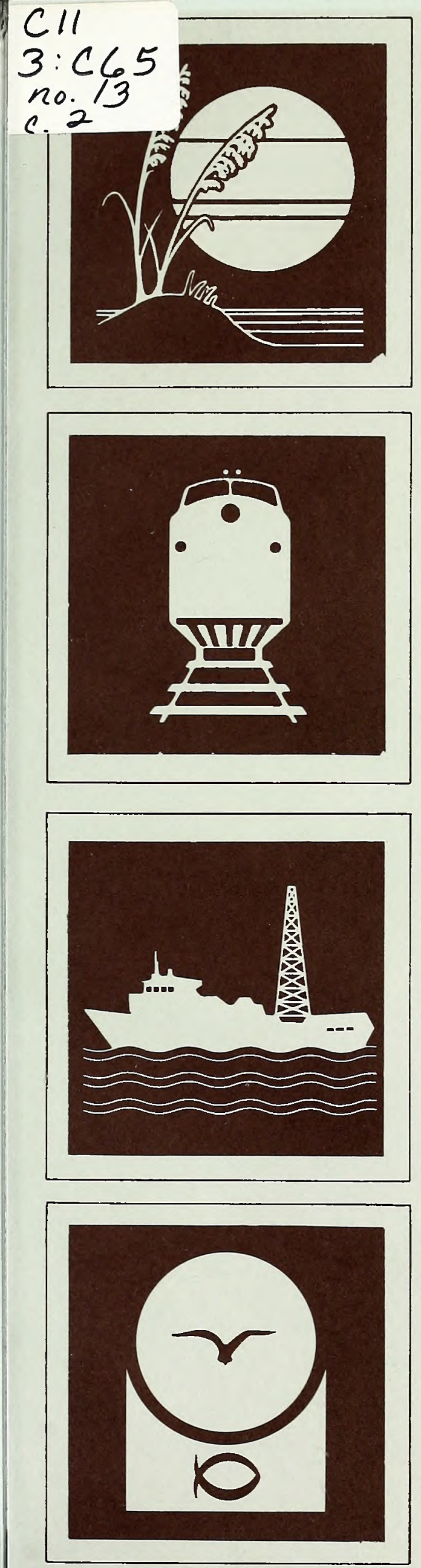

North Carolina Stente Library Raleigh

\section{Beach Communities and Oil Spills:} Environmental and Economic Consequences for Brunswick County, North Carolina

\section{Summary Report}

\author{
Kenneth Creveling Associates \\ McLean, VA
}

JUL 201983

\section{SEPTEMBER 1982}

North Carolina

Coastal Energy Impact Program

Office of Coastal Management

North Carolina Department of Natural Resources and Community Development

CEIP REPORT NO. 13 
To order:

Residents of North Carolina may receive a single copy of a publication free upon request. Non-residents may purchase publications for the prices listed. Because of the production costs involved, some of the publications carry a minimal charge regardless of residency. Prices for these are indicated in the price list as being "for all requests".

When ordering publications please provide the publication number and title and enclose a check made payable to DNRCD. For a complete list of CEIP publications - or to place an order - contact:

Coastal Energy Impact Program Office of Coastal Management

N.C. Department of Natural Resources and Community Development

Box 27687

Raleigh, NC 27611

Series Edited by James F. Smith Cover Design by Jill Miller 


\title{
BEACH COMMUNITIES AND OIL SPILLS: \\ ENVIRONMENTAL AND ECONOMIC CONSEQUENCES FOR \\ BRUNSWICK COUNTY, NORTH CAROLINA \\ SUMMARY REPORT
}

\author{
Kenneth Creveling Associates \\ McLean, Virginia \\ Prepared for the \\ Board of County Commissioners \\ Brunswick County, North Carolina
}

The preparation of this report was financed through a Coastal Energy Impact Program grant provided by the North Carolina Coastal Management Program, through funds provided by the Coastal Zone Management Act of 1972, as amended, which is administered by the Office of Coastal Zone Management, National Oceanic and Atmospheric Administration. This CEIP grant was part of NOAA grant NA-79-AA-D-CZO97.

September 1982

CEIP Report No. 13 



\section{ACKNOWLEGMENTS}

The author wishes to acknowledge with thanks the following individuals and organizations.....

.....for their general guidance and support:

James F. Smith

CEIP Coordinator

North Carolina Office of Coastal Management

John B. Harvey

Planning Director

Brunswick County

....for their assistance in the conduct of local business surveys:

Southport-Oak Island Chamber of Commerce

South Brunswick Is lands Chamber of Commerce

Our sincere thanks, too, to the coastal businesses which provided data and information through surveys and interviews. 



\begin{abstract}
Coastal areas are vulnerable to environmental damage and economic loss from oil spills. This report describes the recreational resources and economic activities in the coastal area of Brunswick County, North Carolina, and discusses their vulnerabilities to oil spills. Detailed economic analyses are made of the commercial fishing industry, recreational fishing and boating, the vacation and retirement housing industry, and seasonal visitation. Surveys of coastal businesses provided much of the data and information contained in these analyses. Potential sources, risks, and types of economic impact of oil spills are identified and reviewed. Additional data and research needed are recommended and guidelines for local planning for oil spill contingencies are outlined.

Technical appendices include reviews of impacts of major oil spills in other coastal locations and descriptions of relevant techniques and procedures for oil spill containment and cleanup. Major benefits of this study are the provision of detailed information to facilitate assessments of economic impacts of future oil spills affecting the County and to aid state and local governments in making decisions relative to coastal development and energy facility siting. While this study focuses on Brunswick County, many methodologies, findings, and recommendations are applicable to other coastal counties and communities.
\end{abstract}


Digitized by the Internet Archive in 2011 with funding from State Library of North Carolina 


\section{TABLE OF CONTENTS}

Section and Title

Page

Acknowledgments

Abstract

ii

Table of Contents

iii

List of Figures

List of Tables

BACKGROUND

Issues and Objectives

Study Area

$\begin{array}{ll}\text { THE COASTAL ECONOMY } & 7\end{array}$

Commercial Fishing Industry 7

Recreational Fishing and Boating 11

Vacation and Retirement Housing Industry 17

Other Visitor Facilities $\quad 24$

Seasonal Visitation and Its Impacts 28

OIL SPILL SOURCES, RISKS, AND IMPACTS 33

Sources of Potential Spills 33

Spill Probabilities and Risks 35

Impacts of Potential Spills 37

RECOMMENDATIONS

Data and Research Needs 41

Contingency Planning 45 



\section{LIST OF FIGURES}

Number and Title

Page

1 Natural and Recreational Resources 3

2 Seafood Industry Establishments 9

3 Recreational Boating and Sport Fishing Facilities 14

4 Residential Development Projects 18

5 Transient Lodgings $\quad 25$

6 Prevailing Wind and Ocean Currents 39

\section{LIST OF TABLES}

Number and Title

Page

1 Summary of Population and Housing Characteristics in the Beach Communities

2 Characteristics of Seasonal Units Rented Through Local Realty Firms, 1980

3 Summary of Key Economic Impacts of the Vacation and

Retirement Housing Industry in the Beach Communities, 1980

4 Summary of Estimated Visitor Days Spent in the Brunswick County Coastal Area, 1980 



\title{
BACKGROUND
}

\section{ISSUES AND OBJECTIVES}

\author{
Need for Study
}

Concerns about $0 i 1$ spills and their impacts on coastal resources and economic activities in Brunswick County came to the surface shortly after plans were announced early in 1979 by the Brunswick Energy Company (BECO) to construct a major oil refinery on the Brunswick County side of the Cape Fear River near Wilmington. Operation of the refinery would have added greatly to the quantity of oil and refined products moving to and from the Cape Fear River, thereby increasing the risks of groundings, collisions, and other causes of oil spills.

In May, 1981 , BECO withdrew its plans, citing financial reasons and a decreasing demand for petroleum products, but impact issues raised by the refinery proposal also surround other oil production and transportation activities. These include the outer continental shelf (OCS) oil and gas exploration and development program, coastal shipping lane traffic, and other ship and barge traffic using local waterways. While risks of acute oil spills from various potential sources are small, impacts can be severe when they occur. Moreover, the aggregate impacts of more common spills from ballast tank flushing and other sources are becoming chronic problems in many coastal areas.

The barrier islands and coastal waters of Brunswick County play important roles in the local economy. The area has historical ties to the commercial fishing industry, but recent economic growth along the coast has been based on a developing recreation and vacation/retirement home industry. These industries and the natural resources on which they depend are exposed and vulnerable to aesthetic and environmental damages and economic loss from oil spills.

\section{Objectives and Scope}

Recognizing its susceptibility to future oil spills, Brunswick County applied for a Federal Coastal Energy Impact Program (CEIP) grant to finance a study of the matter. In 1980, the grant award was made through the North Carolina Department of Natural Resources and Community Development (ONRCD), and a consulting firm, Kenneth Creveling Associates, was retained by the County to conduct a study with three basic objectives in mind:

1). To identify and document those significant resources and economic activities vulnerable to future oil spills.

2). To assess potential impacts of oil spills on these resources and economic activities. 

3). To provide guidance to local officials and residents in dealing with future oil spill situations.

The primary thrust of this study was to document and examine in detail key economic activities in Brunswick County's coastal area which are vulnerable to oil spills. These include the commercial fishing industry, recreational fishing and boating, the vacation and retirement home industry, and other activities which support coastal travel and recreation.

\section{STUDY AREA}

Brunswick County is located in southeastern North Carolina between the port City of Wilmington on the Cape Fear River and South Carolina's "Grand Strand" vacation area, centering around popular Myrtle Beach. The County has a 43mile coastline extending from Cape Fear, on the east, to the South Carolina state boundary, on the west. Several barrier islands separated by river estuaries and tidal inlets characterize this coastline. All but six miles of the coastline face south.

The study concerns that portion of the County generally within a few miles of its coastline. Iricluded within this coastal area are eight small incorporated municipalities--six barrier island communities and two others on the mainland. These municipalities are:

\begin{tabular}{|c|c|c|}
\hline Oak Island & South Brunswick Is lands & Mainland \\
\hline $\begin{array}{l}\text { Caswell Beach } \\
\text { Yaupon Beach }\end{array}$ & $\begin{array}{l}\text { Holden Beach } \\
\text { Ocean Isle Beach } \\
\text { Suncet Roanh }\end{array}$ & $\begin{array}{l}\text { Southport } \\
\text { Calabash }\end{array}$ \\
\hline
\end{tabular}

\section{Natural Resources}

Growth in the Brunswick County coastal region and its attractiveness to residents and visitors are related directly to its natural resources-specifically, its beaches, waterways, salt marshes, finfish and shellfish. These resources and an almost semi-tropical climate continue to be great lures to retirees, vacationers, and fishermen.

The marshes and inside waters of Brunswick County are highly productive resources which most finfish and shellfish species found in the region inhabit for part of their life cycles. The sandy barrier islands, inlets, estuaries, salt marshes, and offshore waters of Brunswick County are havens for a great variety and abundance of fish and wildlife. The waters are popular locations for fishing from surf, boats, and piers. Beaches and marshes serve as habitat and migratory areas for a wide range of birds, mamals, and other wildlife, including a few rare and endangered species. 



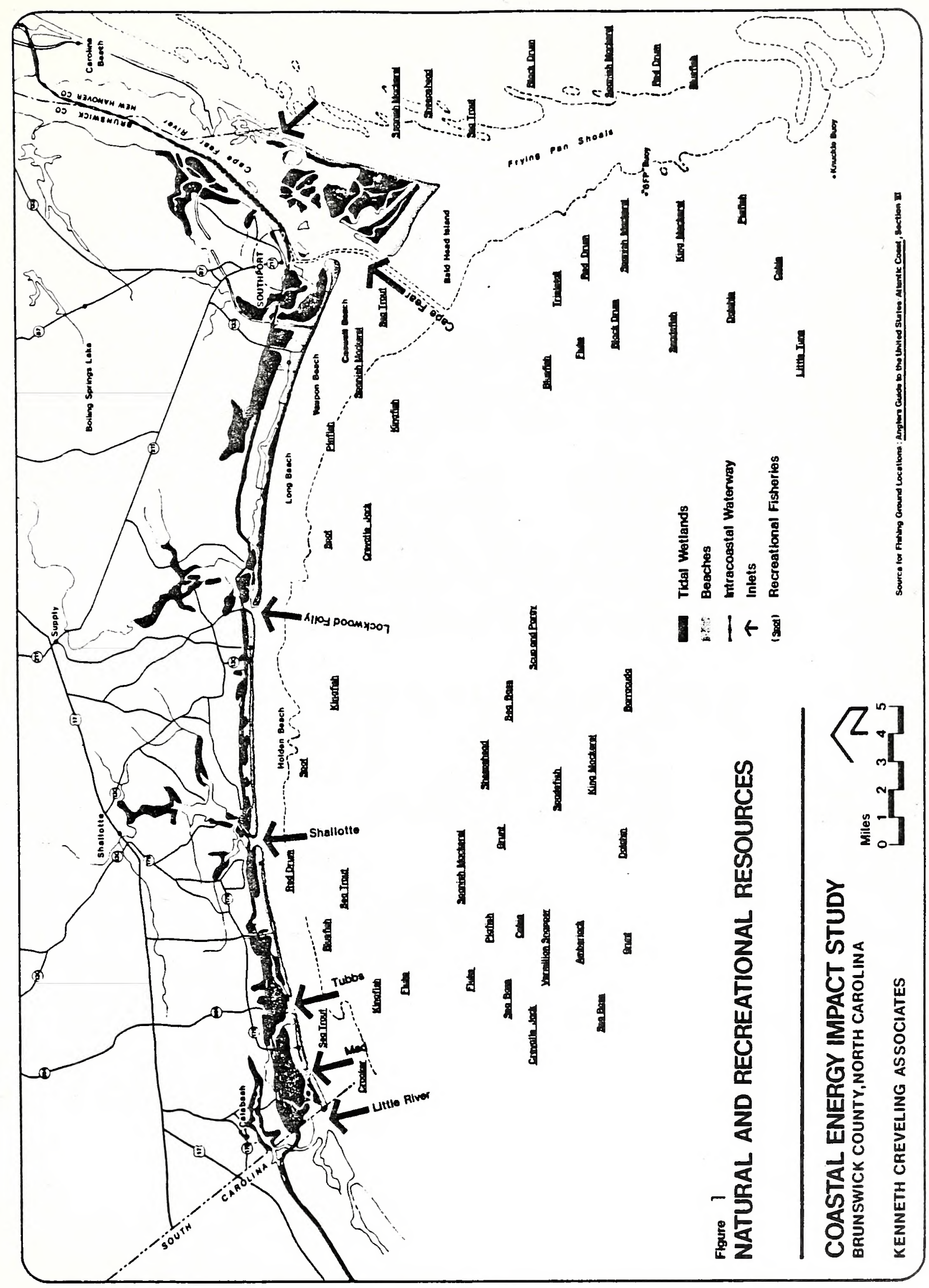


Many species of finfish are found in inside and offshore waters. Leading commercial species include menhaden, grouper, snapper, mullet, sea bass, and spot. Recreational fisheries in the area include bluefish, croaker, drum, flounder, jack, king mackerel, sea bass, sea trout, spanish mackerel, spot and whiting. Principal types of shellfish found locally include oyster, hard clam, blue crab, and shrimp.

\section{Development Patterns}

The permanent population of the six beach communities more than doubled between 1970 and 1980, increasing to over 3,000 residents. Only nine percent of the County's population resides in the beach communities, but these six towns contributed 16 percent of the County's overall growth during the 1970s. Beach communities, are populated by older, more affluent residents, most of whom are retirees.

Over recent years, two-thirds of new housing construction in the County has taken place in the six beach communities, averaging more than 300 new units annually. Sixty percent of building permits for new housing units have been issued in the South Brunswick Islands. Multi-unit condominiums represent an increasing share of new housing starts in the beach communities. This type of housing is restricted in some towns but is prevalent in Ocean Isle Beach. In unincorporated mainland areas near the beach communities, development is characterized largely by mobile and modular homes.

In 1980, 77 percent of all 5,550 housing units in the six beach communities were seasonal cottages and apartments. In the South Brunswick Islands, these seasonal units were 89 percent of all units, versus only 69 percent in Oak Island. In addition to the 4,275 seasonal units in the six beach communities in 1980, there were another 3,690 in other sections of the coast. Between 1975 and 1980 , seasonal housing in the coastal area increased by an estimated 2,750 units, averaging 550 per year. Seasonal housing in the beach communities increased by some 1,275 units during the same period, averaging over 250 units annually.

Businesses dependent on beach, water, and fishery resources in the County generally are small and pay relatively low wages. Most establishments and firms are family operations with few paid employees other than family members. Field survey in early 1981 revealed more than 400 establishments in the coasta) area which are sensitive to non-resident activity and spending. Total numbers of businesses are somewhat equally divided between the Southport-0ak Island and South Brunswick Islands-Calabash areas. The business mix, however, differs by area.

Restaurants and specialty shops are found in greater abundance in the South Brunswick Islands area. This is largely because of concentrations of both in Calabash, the principal tourist center in the coastal area. Greater num- 



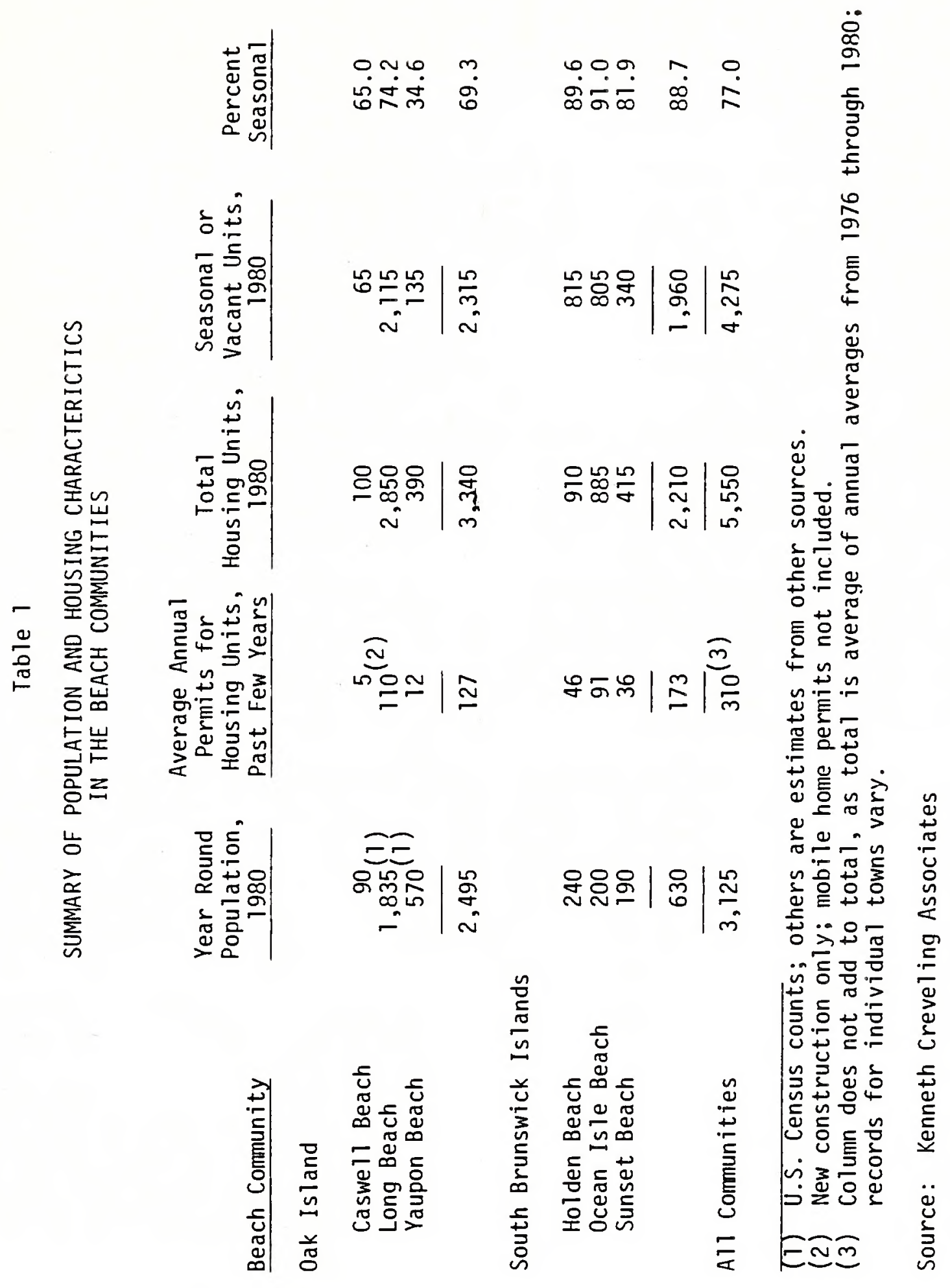


bers of recreation and marine service establishments are also found in the South Brunswick Islands area. The Southport-Oak Island area has the edge in service stations, personal and business service establishments (including banks), and building supply and general merchandise stores. The comparatively large permanent populations of Southport. and Long Beach provide support for these types of business.

Many of the establishments identified during the field survey and others were surveyed by mail questionnaire in early 1981 to determine characteristics of coastal businesses. A few general characteristics are as follows:

- 71 percent attributed more than half of their business sales or receipts to seasonal visitation.

- 57 percent had fewer than five employees during their peak business season.

- 38 percent indicated gross sales or receipts of under $\$ 50,000$, while 36 percent exceeded $\$ 200,000$.

- 55 percent derived at least half of their annual business volume during the summer season (June-August).

Dependency on seasonal visitation varies by location and type of business. Those in the beach communities and Calabash are substantially more oriented to visitors than those in Shallotte and Southport. Only four of ten businesses in these two centers responded that more than half of their business volume was associated with non-residents, versus nine of ten establishments in the beach communities and 100 percent of those in Calabash.

All beach communities have public water supplies, but none have public sewer systems, which limits growth potentials. Lots as small as 5,000 square feet are typical of beach community development, and all are served by on-site waste disposal methods. Only the City of Southport has a public sewerage system, although a few major developments also have common systems. Plans have been drawn to include all beach communities in future regional waste treatment systems. Implementation appears to be a long way off, in view of diminishing Federal funds for sewer construction and waste treatment.

Continued development of Brunswick County beach communities should be relatively unaffected by emerging Federal policies for the nation's barrier islands. Under new regulations, no Federal flood insurance will be made available to undeveloped barrier islands after October 1983. Moreover, the cost of insurance for existing barrier island development may increase in order to reduce or eliminate the Federal subsidy. The U.S. Department of the Interior has recently recommended areas subject to the October 1983 cutoff. In Brunswick County, only the undeveloped Bird Island and the western tip of Sunset Beach adjacent to Mad Inlet are included. 


\section{THE COASTAL ECONOMY}

Economic activities dependent on the coastal attributes and resources of Brunswick County range from commercial and recreational fishing to the construction and rental of seasonal housing. These activities and their associated economic impacts are profiled under the following headings:

- Commercial Fishing Industry

- Recreational Fishing and Boating

- Vacation and Retirement Housing Industry

- Other Visitor Facilities

- Seasonal Visitation and Its Impacts

\section{COMMERCIAL FISHING INDUSTRY}

Commercial fishing is an historically important industry in Brunswick County, although its role in the overall economy has diminished greatly over the years. Still, the industry is the major or secondary source of employment and income to many hundreds of County residents. The industry provides employment not only for commercial fishermen, but also supports a number of seafood packing and processing houses, wholesale and retail outlets, and boat builders. In addition, a great many restaurants along the coast serve seafood from local waters.

All sections of the coast are affected by the commercail fishing industry, with Southport and the Holden Beach area as the centers of activity. In Brunswick County, the industry is highly fragmented and is typified by numerous independent fishermen and small family operations. This fragmentation greatly limits assessment of the dimensions and impacts of the local industry, since a great deal of information on employment, catch, and other indicators is unreported, undocumented, or inaccurate.

\section{The Catch}

For all seafood, the recorded catch reached its peak in 1980. Thirty-seven species were landed in the County having a total dockside value of $\$ 3.7$ million. This reported catch was two percent of the total statewide quantity (in pounds), but six percent of statewide dollar value. The proportionally higher value of Brunswick County landings is attributable to the dominance of shellfish, particularly shrimp and clams, in the county catch. Crabs and oysters are also important. Shellfish landings accounted for three-fourths of the County's total catch value in 1980 . 
Despite, the County's position as a leader in shellfishing, pollution of harvest areas has surpressed the size of the catch over recent years. The County has more than 22,000 acres of oyster and clam harvest bottom, roughly 80 percent of which is off-limits due to pollution.

Summer and fall are the prime local catch seasons for finfish. The summer fishery is primarily deep sea, with groupers and snappers being the principal catches in 1980. The fall fishery, which includes spot and mullet, is closer to shore. The shellfish season varies by species. From conversations with knowledgeable local industry representatives, it was learned that well over half and perhaps as much as 80-90 percent of the local catch is exported out of the County. Oysters tend to be consumed locally, while most clams and about half the shrimp catch are exported because of their high cost relative to the local market. Local restaurants rely heavily on imported shellfish to maintain adequate supplies throughout their business seasons. Finfish used by restaurants in the area include flounder and trout, most of which are imported from coastal areas in northern sections of the State.

Brunswick County also is a leader in landing and processing "industrial fish", principally menhaden. Industrial fish were an estimated 95 percent by weight and 40 percent by value of total commercial landings recorded in the County in 1980. With industrial fish included, Brunswick County would rank second only to Carteret County in total quantity of catch.

Menhaden are surface-running fish which migrate north and south along the coast in compact schools, generally close to shore. Large boats frequently can be seen close to shore following schools. Fish spills have become a somewhat normal occurrence, but are a particular nuisance when they occur along beaches during the tourist season.

\section{Employment and Income}

Commercial Fishing. An estimated 2,500 persons may have derived some part of their livelihood from fishing in 1979, according to the Brunswick County Planning Department. Only a few hundred, however, are dependent on fishing for most or all of their incomes.

Rising operating costs and dependency on variable local shellfish resources make commercial fishing a very fragile sector of the local economy. Many fishermen in the County barely maintain a subsistence level of earnings and must seek other sources of income. The average dockside value of catch per fishermen in Brunswick County is only about half the statewide average. In real dollar earnings, fishermen in the County and elsewhere have probably lost ground over the last 10-15 years, despite recent increases in landings. 


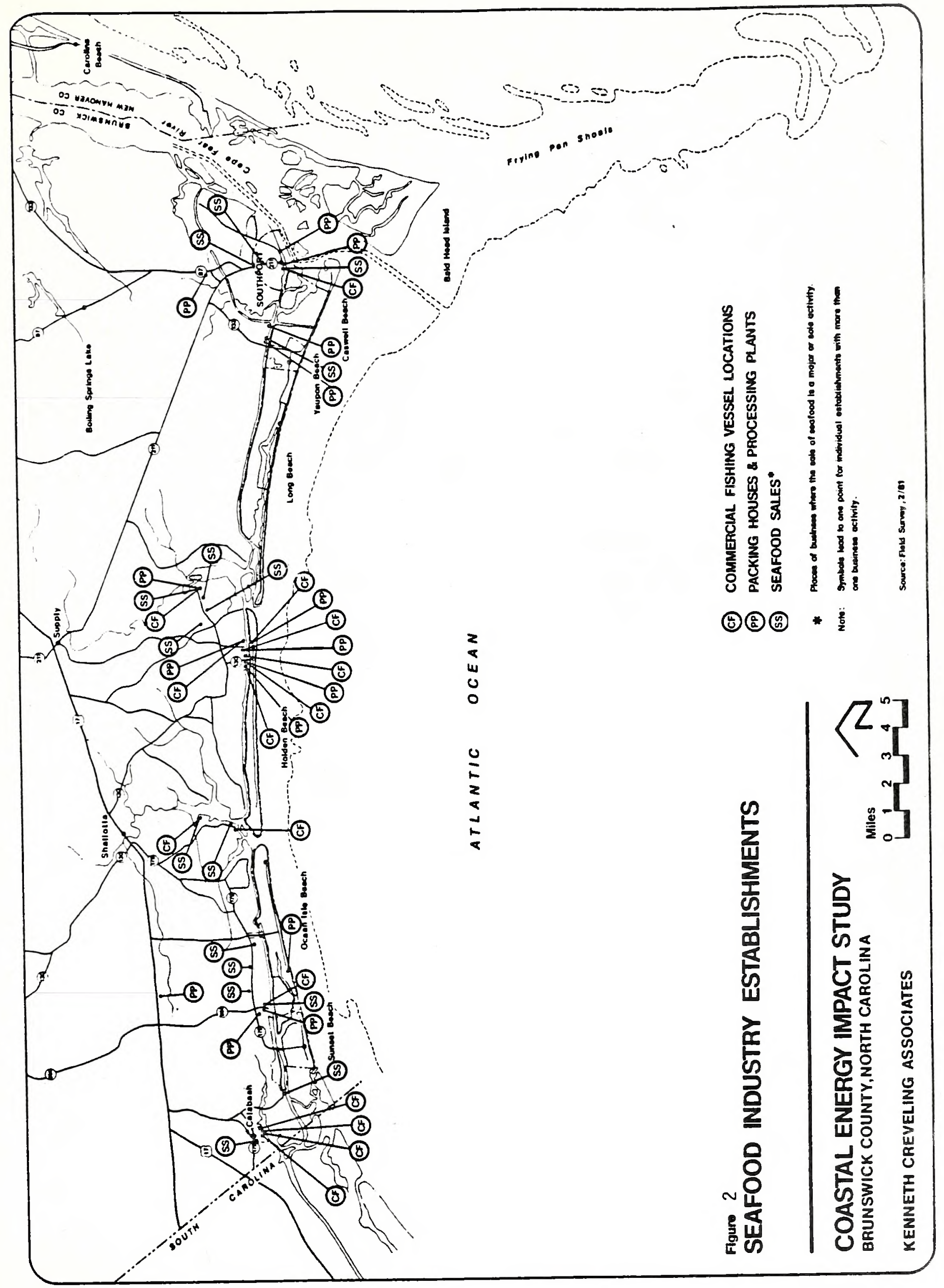




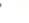


Brunswick County was home port in 1980 for an estimated 400-450 full-time commercial fishermen who derive at least half of their incomes from fishing. In addition, Brunswick County probably atiracts many non-resident fishermen because of the numbers of packing and processing facilities, dealers, and retail outlets (e.g., Calabash restaurants) in the County. The snapper/ grouper and swordfish fisheries, for example, have brought a number of outof-state fishermen in local ports during recent years.

Shrimp leads all fisheries in generating full-time employment, but Standard Products Co., the menhaden processor near Southport, maintains the largest individual fishing operation.

State income tax records reveal an average gross income of $\$ 7,900$ for commercial fishermen in 1979, based on a sample of returns. This was identical to the 1977 average from the same source, indicating declining real incomes (after inflation), despite substantial increases in the quantity and value of the commerical catch. By comparison, menhaden fishermen do relatively well, having averaged an estimated $\$ 12,900$ for Brunswick County landings in 1980 .

Packing and Processing. Packing and processing operations in Brunswick County include oyster shucking, crab picking and packing, and menhaden processing. Several firms in the area are wholesale dealers. A few, such as oyster houses, also sell at retail. A field survey conducted in February 1981 revealed 15 establishments in the County which appeared to be packing houses or processing plants.

Five seafood firms responded to the questionnaire survey conducted in 1981 . Firms ranged in size from two to 45 full-time employees during their peak season. Estimates of gross sales or receipts ranged from less than $\$ 50,000$, for the smallest firm, to over $\$ 2.5 \mathrm{million}$, for the largest. Businesses were dependent on coastal area visitors (i.e., sales to restaurants, etc.) to varying degrees. The largest firm surveyed indicated that 75 percent of its business was attributable to visitation. Oyster shucking and packing houses are most active generally from September through March/April, and are closed or maintain a much reduced operation during the rest of the year. Other firms are active generally during the March/April to November/December season.

For 1980, the NC Bureau of Employment Security Research (BESR) reported nine firms in the County, with an average annual employment total of 204 . This was sharply down from the 263 employees (annual average) for the same number of firms reported in 1979. The drop was associated with declines in commercial landings of crabs, oysters, and menhaden--three principal species processed locally. Similarly, average annual payrolls per worker declined from $\$ 10,770$ in 1979 to $\$ 10,610$ in 1980 . 

Estimated per worker averages and total payrolls by sector for 1980 are as follows:

Seafond Menhaden

Avg. Payrol1/Worker $(\$)$

8,900

15,600

Total Payroll(\$)

1.4 million

0.8 million

Avg. Annual Employment (No.)
50

Total estimated 1980 payrolls from packing and processing operations in the county were $\$ 2.2$ million. The total value of shipments or products sold by County firms in 1980 is conservatively estimated to have been $\$ 13.0$ million. Of this amount, the seafood sector accounted for $\$ 7.0$ million (54 percent), and the menhaden processing sector for $\$ 6.0$ million (46 percent).

Wholesale Trade. This sector consists of three types of dealers: those who catch and sell, those who buy from fishermen and sell, and those who buy from other dealers and sell. Many fishermen in the County fall into the catch and sell category. Several local packing/processing firms are also wholesale dealers. In 1980, Brunswick County had 30 dealers who buy from fishermen and se?l according to the U.S. National Marine Fisheries Service (NMFS). Most operations are very small, averaging only 1-2 persons.

The State issued licenses to 104 "seafood dealers" in the County in 1980. Licensees include numerous individuals and retail stores and several shucking/packing houses. Only Carteret County, with 116 licensees, exceeded the Brunswick County number. The seafood catch in Carteret County, however, was 16 times greater in quantity and five times greater in dockside value than the Brunswick County catch in 1980. This comparison illustrates the fragmented, small business nature of the local industry.

Payrolls in the fish and seafood wholesale sector were an estimated $\$ 140,000$ in 1980, averaging $\$ 4,650$ per worker. Total sales of goods wholesaled by Brunswick County firms in 1980 were an estimated $\$ 1.75$ million.

Boat Building and Repair. Boat building and repairing is a minor industry in Brunswick County, but directly tied to commercial fishing. Five firms with annual average of 20 employees were reported in BESR data for 1980 .

\section{RECREATIONAL FISHING AND BOATING}

Sport fishing recreational boating are among the most popular pastimes of seasonal visitors and permanent residents in Brunswick County. Millions of dollars flow through the local economy annually from a variety of facilities and services in the coastal area which cater to fishermen and boat owners. 


\section{Coastal Fishing}

The fishing season in Brunswick County extends generally from early spring (March-April) to late fall (November-December). Spring and fall months are favored for surf and pier fishing by serious fishermen, although pier usage peaks during summer months with the arrival of family vacationers and seasonal residents. Summer months are preferred for offshore and deep sea fishing because of more favorable sea and weather conditions. Boat fishing in inside waters occurs throughout the season, but also tends to peak during the warmer months.

Most species found in local waters can be fished successfully for several months, but many are better at certain times of the year. Spring and fall, for example, are the best for bluefish, croaker, trout, and kingfish (whiting). Others, including flounder and spanish mackerel, are most in evidence during summer months. The fall months are best for spot and king mackerel, among others.

An estimated 425,000 saltwater fishing occasions (days or parts thereof) generated expenditures of $\$ 4.9$ million in Brunswick County. Average expenditures per occasion were estimated to be $\$ 11.50$, excluding costs of lodging, travel, and capital goods. These estimates were based on data from a 1979 NMFS survey of marine recreational fishing in the South Atlantic states.

Fishing tournaments have become a popular way to extend the tourist season in coastal areas. The U.S. Open King Mackerel Tournament held in local waters has a three-year history, beginning in 1979 with 314 boats registered and carrying some 1,500 fishermen. The 1981 tournament drew an estimated 472 boats and over 2,500 fishermen. Many fishermen are accompanied by family and friends, suggesting that the three-day tournament may have generated as many as 5,000 visitors to Brunswick County in 1981 and spending of $\$ 0.25$ million on food, fuel, lodging, and other local goods and services.

\section{Recreational Boating}

Boating in Brunswick County is generally incidental to fishing. Lacking the large open water areas characteristic of northern coastal counties, pleasure boating and sailing are relatively less important recreational pastimes in local waters. Nevertheless, motorboat registrations in the County increased from 35 per 1,000 residents in 1970 to 100 boats per 1,000 residents by 1979 . Growth of local registrations results from several factors, among which have been the development of numerous lagoon homesites in the South Brunswick Islands.

The ratio of pleasure boats with commercial fishing gear to total motorboat registrations in the County is exceeded in only one other coastal county, indicating the more utilitatian nature of boating activity in Brunswick County than that of many other coastal counties. 

Boating activity by local residents and visitors picks up in March/April and tapers off around November, generally corresponding to the fishing season. Peak activity occurs during the summer months, influenced largely by the arrival of non-resident homeowners.

The Intracoastal Waterway accommodates a range of commercial and recreational traffic, including trawlers, barges, sailboats, small power boats, and large motor yachts. Counts at the Ocean Is le Beach drawbridge showed over 4,000 sailboats and yachts in 1980. Distinct peaks occur in the spring and fall, with heaviest traffic occurring in October and May. The spring peak, which begins in April and continues into June, results from interstate traffic heading north along the Waterway. Interstate movements to the south are the basis for the more exaggerated fall peak, which begins abruptly in October and ends in November. This long-distance Waterway traffic is unrelated to the local recreational boating season, which peaks during the summer months. The same traffic is probably not significant in local economic terms, since much of its may traverse the County without stopping for goods and services.

\section{Local Facilities and Services}

Facilities and services found in the County include fishing piers, charter and head boat services, marinas, and launch ramps. The center for fishing and boating is Southport, but facilities and services are located all along the coastline and Intracoastal Waterway.

Fishing Piers. Brunswick County has six commercial ocean fishing piers-three on Oak Island and one each in Holden Beach, Ocean Isle Beach, and Sunset Beach. All have food service, amusement/game rooms, and rent fishing tackle. Three piers provide overnight accommodations on or near the site. Piers are open from April through November. Ranging in length from 800-1,100 feet, they extend beyond the breaker zone, increasing the variety of fish available to anglers.

Piers averaged an estimated 35,000 visits in 1980, but ranged from less than 15,000 to over 50,000 for individual piers. Generally, those with on-site lodging had the highest overall attendance. The summer season (June-August) accounts for half of total annual business at most piers. During this 1980 season, piers averaged 150-200 patrons daily.

All six piers generated an estimated $\$ 1.1 \mathrm{million}$ in revenues in 1980 , exclusive of lodgings, but including entry fees, bait sales, food sales, and receipts from amusements on the site. Overall revenues average to approximately $\$ 180,000$ per pier. Commercial piers provided an estimated $\$ 330,000$ in payrolis in 1980 and 49 full-time equivalent jobs, averaging around eight per pier.

Brunswick County's piers accounted for an estimated 49 percent of all local fishing occasions, but only 20 percent of expenditures. 



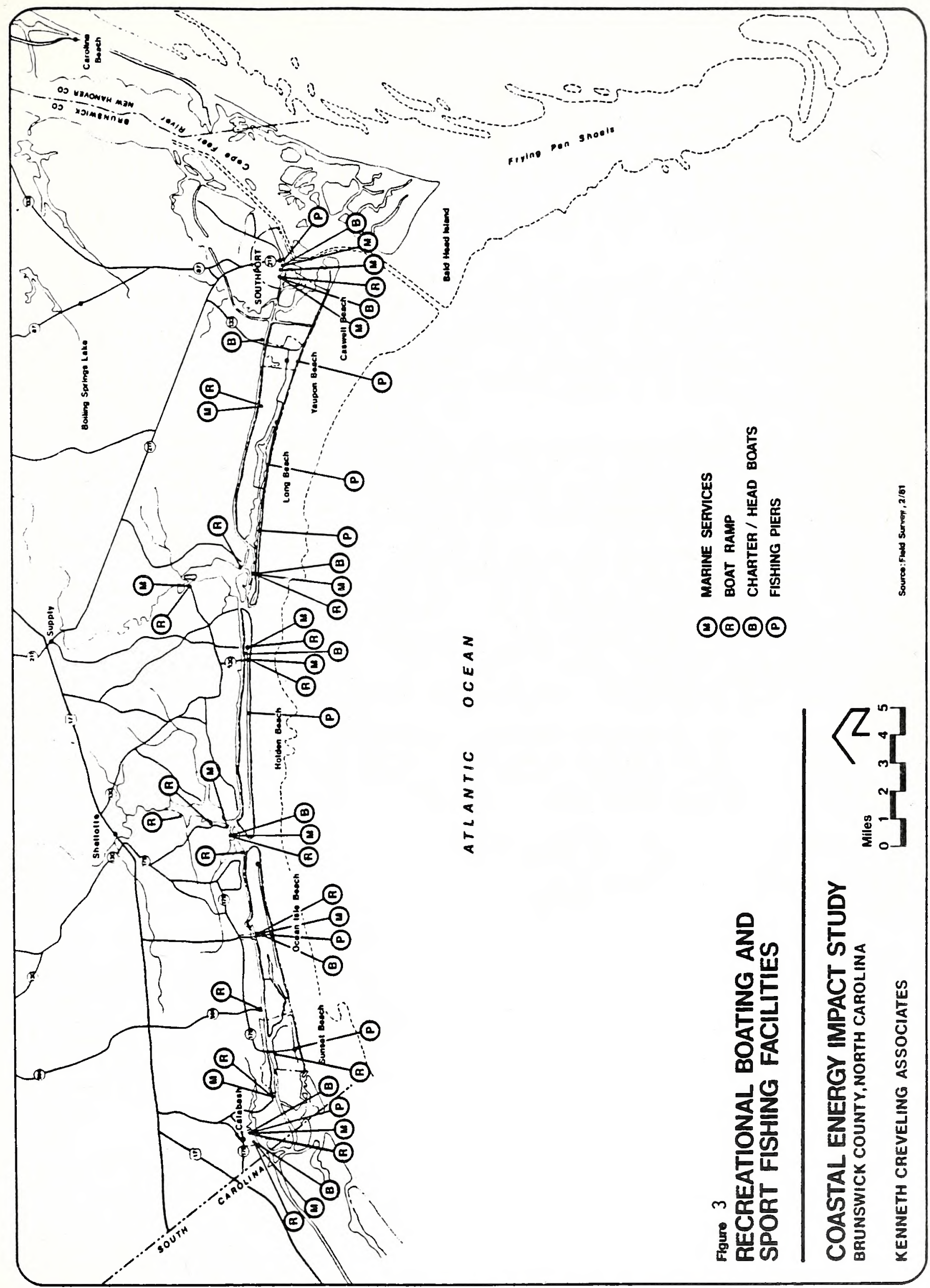



Charter and Head Boat Services. Charter and head boats provide opportunities for deep sea fishing to novices and others not having proper equipment or means of access to offshore fishing grounds. Charter boats cater to small cohesive groups (usually 4-8) for a group fee. Head boats, also called party boats, cater to much larger groups of unrelated anglers for individual (per head) fees. Thirteen charter boats and three head boats operated in the County in 1981 .

Charter fishing takes place from early spring to late fall, but has only an approximate 150-day season. Weekend and weekday fishing is typical during summer months, while spring and fall months are limited generally to weekend fishing. Only about 60 percent (90 days) of this season may actually be fished because of inclement weather. The summer months account for onethird to one-half of annual usage, but charter groups tend to be larger per day in spring and fall months.

Charter fees vary by operator and size of group and averaged $\$ 250$ in 1981 for a 6-person charter, exclusive of food and drink. The 13 charter boats in the County generated estimated gross fees of $\$ 292,500$ in 1981, averaging less than $\$ 25,000$ per boat. Head boats generated another $\$ 95,500$ in fees.

Neither charter nor head boat fishing are sources of year-round employment to operators and employees. Charter boats typically have a crew of two (captain and mate), but only fish for perhaps 90 days or less per year. Head boats have larger crews, but also fish a limited season. Both are relatively marginal economic ventures, in which operators often double as commercial fishermen or require other income sources. Employment is seasonal and probably averaged not more than 25-30 part-time jobs during 1981 , many of which may have been filled by members of boat operator's families.

In the aggregate, charter and head boat fishing accounted for an estimated $\$ 388,000$ in gross income to operators and 13,400 fishing occasions in 1981. These estimates represented approximately seven percent of saltwater fishing expenditures and three percent of fishing occasions in the County.

Marinas and Landings. Brunswick County has 18 marine commercial establishments along the Intracoastal Waterway and connecting water areas. Facilities range from full-service marinas to restaurant docks. Concentrations are found in Southport, Shallotte Point, and Calabash.

In general, local establishments are modest both in size and services provided. Most are oriented to local boating and fishing rather than long distance Intracoastal Waterway traffic. Typical features include a launch ramp, dock, and fuel sales. Local marinas have an aggregate capacity of approximately 175 slips, in contrast to New Hanover County and Horry County (Myrtle Beach and vicinity), which have approximately 1,000 and 600 , respectively. 

Summer and fall are the peak seasons for local marinas and landings. Two establishments which responded to the questionnaire survey indicated that these seasons accounted for $75-80$ percent of all boats stopping for service (e.g., fuel). Telephone interviews with other establishments confirmed this general seasonal business pattern. The Southport Marina, on the other hand, noted a higher business volume in spring and fall months, as a result of fuel and other sales to large yachts passing through on the Waterway. While indicating that the number of boats may be greater during the summer, they are smaller and consume much less fuel than waterway-oriented boats, which peak in the spring and fall.

Assessment of the economics and impacts of commercial marinas and landings in the County was precluded by lack of data and the widely different mix and scale of facilities and services at individual establishments. At the State level, marine service establishments averaged an estimated $\$ 175,000$ in gross income in 1979, but this average is likely to be much higher than that in Brunswick County.

\section{Economic Impacts}

Assessment of income and employment impacts of local recreational fishing and boating excludes costs of lodging and travel to/from the area, since the major portions of these activities are incidential to other reasons for visiting the coastal area. Omitting these expenditures, recreational fishing and boating in the County may be as much as a $\$ 10$ miliion industry, the largest component of which is saltwater finfishing. Local expenditures for this fishing activity were estimated to have been $\$ 4.9 \mathrm{million}$ in 1979 , as previously noted, or $\$ 5.5$ million in 1980 , after adjusting for inflation. The balance is composed of expenditures on marine equipment and supplies, repair services, pleasure boating activity, and recreational shellfishing. Principal components are assessed below.

Saltwater Finfishing. An expenditure level of $\$ 5.5$ million in 1980 , would support an estimated $\$ 1.38 \mathrm{million}$ in payrolls and 205 full-time equivalent jobs. These estimates encompass fishing pier operations and charter and head boat services, as well as payrolls and employment associated with expenditures made by fishermen at marinas, food stores, restaurants and gri11s, and other places of business. Many fishing-related jobs are part-time; thus, actual employment will be greater during the peak season than the number of equivalent full-time jobs estimated above.

Marine Retail Trade. Gross sales by boat and marine supply dealers in the County totalled $\$ 1,587,000$ in FY 79-80, as shown by the records of the NC Department of Taxation. These sales generated an estimated $\$ 143,000$ in local payrolls and 18 equivalent full-time jobs. Employment is highly seasonal, having fluctuated from less than 10 jobs in the winter months to over 30 during the peak season of FY 79-80. 



\section{VACATION AND RETIREMENT HOUSING INDUSTRY}

Vacation and retirement housing along the coast is the mainstay of the County's recreation/tourism industry. Moreover, an increasing percentage of coastal residents are retirees who settle in the area, in part, because of its amenities and recreational resources. Vacation homes and apartments constitute the major share of overnight lodging in the County by a wide margin, accounting for over 90 percent of capacity in the coastal area.

Outside the City of Southport, the majority of housing is seasonal. Retirees occupy the largest share of homes used year round in the beach communities and in unincorporated coastal mainland sections. Nearly four of every five new units are built as second homes for use by out-of-town owners and/or renters.

Motivations for investments in coastal properties range from immediate retirement to speculation and equity appreciation. On or near the oceanfront, principal motivations are personal use and financial return from rentals and equity appreciation. Properties away from the oceanfront or on the mainland more often are sought by those planning immediate or eventual retirement.

Over the long term, demographic and economic factors favor continued growth of vacation and retirement housing in coastal areas. The extent of growth is more likely to be limited by physical and regulatory factors, which affect the amount and cost of buildable 1and. The future growth of Brunswick County is not significantly limited. The supply of oceanfront land is diminishing, but this trend is somewhat offset by the increasing construction of condominiums.

\section{Market Characteristics}

Subdivision Activity. Brunswick County has the distinction as the most subdivided county in North Carolina. The county's physical characteristics, low taxes, and absence of strong land use regulations have encouraged numerous subdividers and developers to plat thousands of lots in the coastal area.

Federal records indicate that Brunswick County accounts for 15-20 percent of al1 reported subdivision lots in North Carolina. In the order of 48,000 lots in some 100 different subdivisions in Brunswick County were reported by HUD's Office of Interstate Land Sales Registration through 1980 . Largest among these subdivisions is Boiling Springs Lake, with over 10,800 lots.

Seasonal Housing. Housing used on a seasonal or occasional basis in the coastal area has grown from 5,225 units in 1975 to an estimated 7,965 units in 1980--a 52 percent increase. The average annual rate of growth since 1975 has been 550 units. The six beach communities averaged 255 new units annually, while nearby unincorporated areas have grown at a faster rate-an estimated 296 units annually. 



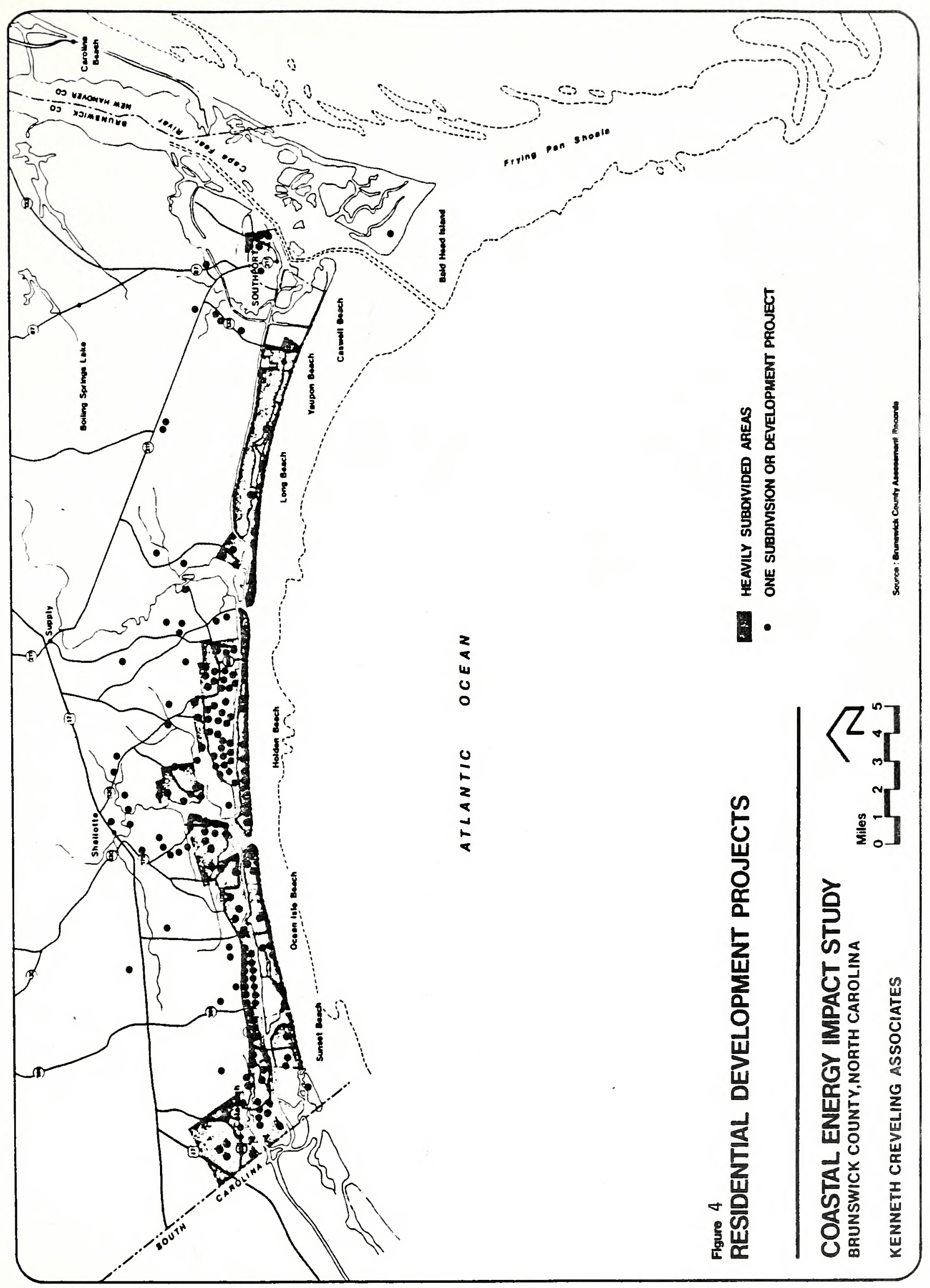



Most units are single-family "cottages", but multi-unit condominiums represent an increasing share of starts in the beach communities. This type of housing will be in even greater demand in the future, as land on or near the beachfront becomes increasingly scarce and housing costs escalate.

Price. In the beach communities, the major price variable is land. Costs of lots vary widely from one community to another, as well as within a community. Lots are highest priced along the oceanfront, fall off dramatically moving away from the oceanfront, and rise slightly adjacent to natural and man-made waterways. Costs of waterway lots generally reflect dredging and bulkheading costs. These patterns are consistent for all beach communities, but differences among communities are substantial.

Lot prices increase from east to west along the coast, with Sunset Beach having the highest-priced lots. A number of factors account for this phenomenon, including beach conditions, community character, amount of available oceanfrontage, and proximity to the Myrtle Beach area. In Ocean Isle Beach and Sunset Beach, the cost of oceanfront lots exceeds the average cost of homes erected on them. Average costs of site-built homes ranged up to $\$ 50,000$ during $1980-81$, depending on location.

Seasonal Rentals. Rentals of seasonal units provide substantial incomes to owners and local realty firms, but affect less than half of all seasonal units in the six beach communities. Proportions of rented units to total seasonal units vary, however, by community. Of 2,270 seasonal units on Oak Island, only 22 percent are rented through local firms. In the South Brunswick Islands, 53 percent of an estimated 1,925 seasonal units are rented through local firms. Altogether, over 1,500 units were rented through local firms in 1980.

An estimated 80-90 percent of a 11 beach community rentals are advertised and managed by local realty firms as a regular business activity. More than half (52 percent) of all agency-rented units in the beach communities are oceanfront, the prime rental location.

Seventy percent of the agency-managed rental units were single family cottages. Nineteen percent were separate apartments in larger cottages or units in duplex dwellings. Eleven percent of units were located in multiunit projects, including condominiums.

Rents increase moving west along the coast from Oak Island to Sunset Beach for two principal reasons:

- Overall averages in Oak Island and Holden Beach are held down by older and smaller units.

- Ocean Isle Beach and, particularly, Sunset Beach are nearer to Calabash and South Carolina's "Grand Strand". 


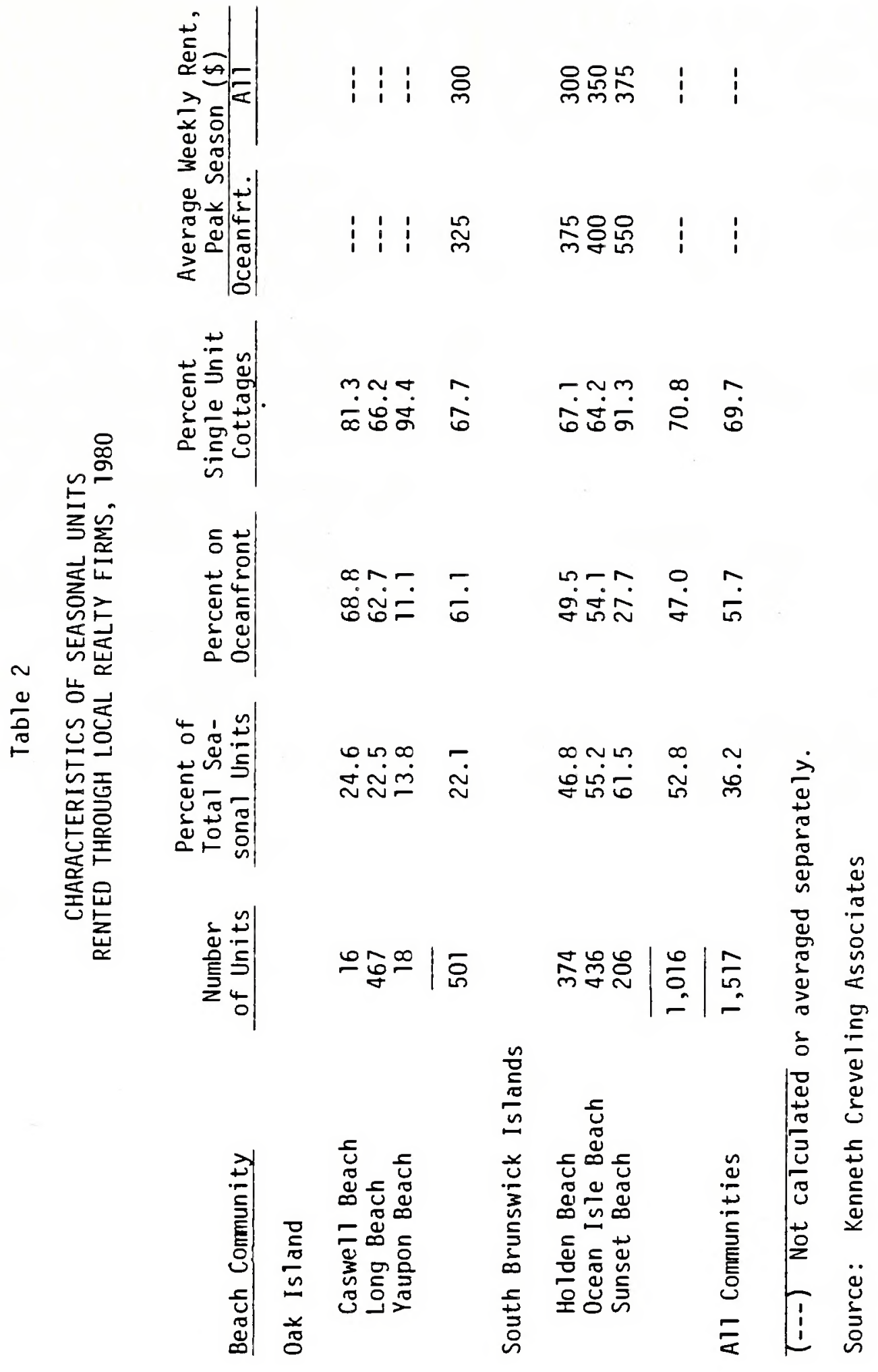



While rents are comparable for newer, larger single family cottages in all beach communities, a mix of older units, cottage apartments, duplex units, and multi-family units affects average rents for each community. This is particularly true for oceanfront units, which range from $\$ 325$ per week, on average, in Oak Island to $\$ 550$ in Sunset Beach.

Units on the oceanfront have the highest rents, with those on natural waterways next. Second row and dredged canal units are about equal in price. Rents fall-off substantially away from the oceanfront. Rents for second row units, on average, are one-third less than oceanfront units.

Occupancy. Rental units in the South Brunswick Islands have an estimated average annual occupancy rate of 35 percent, compared with 40 percent in Oak Island. Some local motels and rental homes on Oak Island are sources of temporary housing for CP\&L nuclear plant workers and their families during fuel change and repair cycles.

During the summer months (June-August), occupancy averages 90 percent, reaching almost full occupancy during July and August. Spring and fall months average 25-30 percent occupancy, while winter months average less than five percent. The average length of stay for renters during the sumer is one week. Saturdays are the peak turnover days. Some renters (approx. 20-25 percent) stay two weeks or longer. At other times, weekend use is typical.

Owner and Visitor Origin. Seasonal units are owned largely by North Carolina residents. Seasonal visitors are more widely distributed. It is estimated that most owners live within four hours driving range of their property, but that typical renters travel much longer distances. North Carolina is the leading state of origin for renters, but South Carolina and states north and west of North Carolina are also well represented.

\section{Economic Impacts}

The vacation and retirement housing industry in Brunswick County has widespread impacts on the local and regional economies. Direct impacts include:

- Incomes to developers, builders, and owners from sales and rentals.

- Commissions to real estate agents and property management firms.

- Employment and payrolis generated by construction and maintenance activities.

- Sales of building materials, appliances, and furnishings. 

Real Estate Employment and Income. Sales and rentals of vacation and retirement properties in the beach communities supported an estimated 40 real estate offices, 170 average annual employees, and payrolls of nearly $\$ 1.5$ million in 1980. Two dozen of these firms serve as rental agents and several are also involved in home building. Those responding to the questionnaire survey averaged 7-8 full-time and part-time employees during the summer season and 4-5 employees in the off-season. Altogether, there were 49 real estate offices in the coastal area in 1980, plus sales offices for 10 land development companies or projects.

Rentals. Rentals in the six beach communities generate income to owners and commissions and management fees to local real estate agents and property managers. In 1980, owners grossed an estimated $\$ 8.1$ million from seasonal rentals of 1,517 units handled through local firms. Local firms received an estimated $\$ 0.9$ million in management fees from these rentals.

Maintenance and Repair. Virtually all units need maintenance or repair annually. Oceanfront units average $\$ 450$ in maintenance and repair costs annually (1980 dollars), while non-oceanfront units average $\$ 250$. Oceanfront units are larger, as a general rule, have higher occupancy rates, and are more exposed to the elements. The estimated local economic impact of maintenance and repair activities in connection with vacation and retirement housing in the six beach communities in 1980 is $\$ 1.24$ million.

Construction. The typical beach community unit averaged $\$ 50,000$ in new construction cost in 1980. Of this, labor cost is an estimated 35 percent on $\$ 17,500$ per unit. Each unit will generate 1.8 jobs in the local construction sector, versus less than 0.2 jobs per mobile home. At 1.8 construction-related jobs per new unit, the annual employment impact based on the number of permits issued in 1980 (i.e., 310) was 560 jobs, not including builders and general contractors. It is estimated that another 150 construction jobs were required in connection with new vacation and retirement housing in other sections of the coastal area, for a total of 710 jobs.

Building Materials and Supplies. Costs of lumber, hardware, and other materials and supplies represent an estimated 40 percent of total costs, or $\$ 20,000$ for the typical beach community unit. Based on 310 construction permits issued for dwelling units in the beach communities in 1980, an estimated $\$ 6.2$ million in materials and supplies were purchased. These purchases translate to payrolls of $\$ 560,000$ and employment of 50 persons.

Summary. The vacation and retirement housing industry in the six beach communities had an estimated direct economic impact in excess of $\$ 25$ million in 1980, not including property sales. The impacts on residents and businesses in Brunswick County may only be half this total. Significant shares of labor and building materials come from other counties. Most owners of rental units are non-residents, therefore, rental incomes largely leave the County. 

Table 3

SUMMARY OF KEY ECONOMIC IMPACTS

OF THE VACATION AND RETIREMENT HOUSING INDUSTRY

IN THE BEACH COMMUNITIES, 1980

Type of Impact

Average

Impact per Unit Total Impact

Real Estate Employment and

Payroll (40 offices)

- Annual average jobs

- Annual payrolls

NA

NA

170

$\$ 1.5$ million

Seasonal Rentals (1,517 units)

- Income to owners

- Commissions/fees to local agents

$\$ 5,340$

$\$ 8.1$ million

$\$ 600$

$\$ 0.9$ million

Maintenance and Repair $(5,550$ units) (1)

- Labor and materials cost

variable

$\$ 1.24$ million

Construction (310 units)

- Jobs (full-time equivalent)

- Payrolls

- Total value (excluding land)

Building Materials and Supplies

(310 units)

- Retail cost

- Payrolls

- Jobs (full-time equivalent)
1.8

$\$ 17,500$

$\$ 50,000$

$\$ 20,000$

$\$ 1,800$

0.16
560

$\$ 5.4$ million $\$ 15.5$ million

NA Not applicable.

(1) All residential units counted as either vacation or retirement homes.

Source: Kenneth Creveling Associates 



\section{OTHER VISITOR FACILITIES}

Other businesses strongly affected by visitors to the coastal area include motels, campgrounds, restaurants, food stores, specialty shops, gas stations, golf courses, and amusements. Selected types of visitor-oriented facilities are reviewed below.

\section{Motels and Campgrounds}

Motels and campgrounds constitute a minor ten percent of total overnight capacity in the coastal area, but a larger share of available capacity during off-season months when most seasonal cottages and apartments are closed. Accommodations in the County are smaller, on average, than those of many other coastal counties. According to state directories, Brunswick County had only one motel with over 50 rooms and one campground with over 100 sites in 1980 .

The Brunswick County coastal area contained 25 motels/inns and 10 campgrounds with an estimated 486 rooms and 464 campsites in 1980. The majority of motel units and campsites are found in the beach communities. Two-thirds of the motel units are located in the Southport-0ak Island area, while over 80 percent of the campsites are located in the South Brunswick Islands area.

\begin{tabular}{cccc}
$\begin{array}{cccc}\text { Type of } \\
\text { Unit }\end{array}$ & $\begin{array}{c}\text { Southport-Oak } \\
\text { Island area }\end{array}$ & $\begin{array}{c}\text { South Brunswick } \\
\text { Islands-Calabash area }\end{array}$ & $\begin{array}{c}\text { Total } \\
\text { Units }\end{array}$ \\
\cline { 2 - 3 } Motel/inn & 322 & 164 & 486 \\
Campground & 74 & 390 & 464 \\
& $\overline{396}$ & $\overline{554}$ & $\overline{950}$
\end{tabular}

Local motels and campgrounds have a collective average annual occupancy rate of 40-45 percent. The industry-wide break-even rate is 60-65 percent, but much lower occupancy rates are not uncommon in seasonal vacation and tourist areas. In such areas, closing a business for part of the year is one means of achieving a higher effective occupancy rate. Lodgings in Southport and Shallotte, in general, are open all year, since they cater to more than beach visitors. In contrast, most lodgings in the beach communities close during the winter months. Only one campground and a few motels in or near the beach communities remain open year round.

Revenues generated by coastal area motels and campgrounds totalled an estimated $\$ 2.3$ million in 1980 . Of this total, motels accounted for $\$ 1.9$ million and campgrounds for $\$ 0.4$ million. 


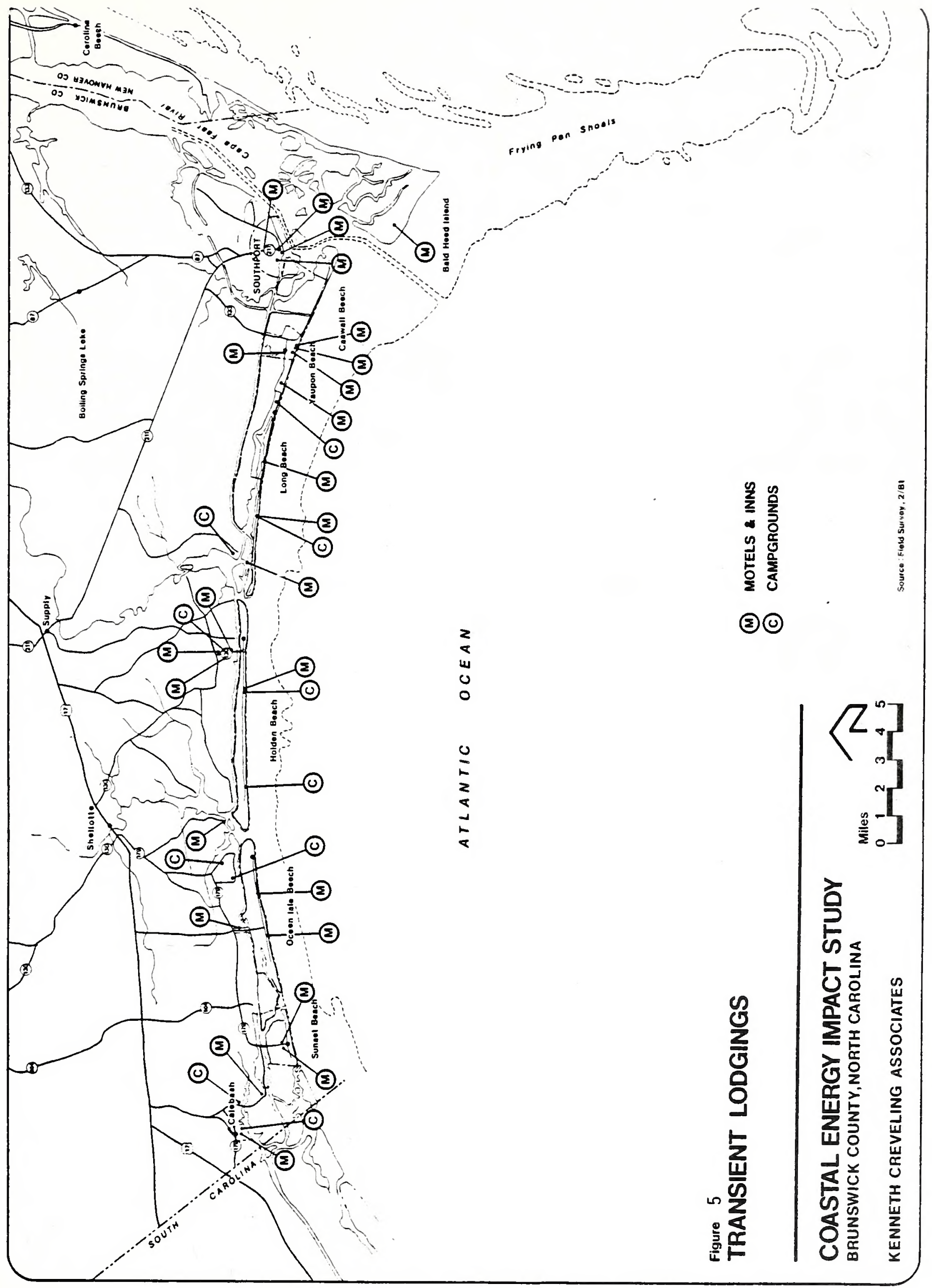


These revenues averaged an estimated $\$ 3,800$ per room and $\$ 900$ per campsite in 1980. Actual revenues vary by establishment size and location; thus, these unit averages should not be used to assess individual businesses. Highest average revenues per motel room are associated generally with the largest facilities, both in the beach communities and on the mainland. Generally, establishments with 40 or more units averaged $\$ 6,500$ per room, while those with less than 40 units averaged $\$ 3,000$ per room. Revenue estimates ranged from around $\$ 2,000$ or less per room for small seasonal motels (10 units or less) to over $\$ 8,000$ per room for the largest yearround motel in Southport.

Motels and campgrounds in the County are aimost entirely family-run businesses. Only half have payrolls. Most establishments in the County are simply too sma11, on average, to maintain payroll levels comparable to many other coastal counties. Payrolis and equivalent wages in the coastal area were $\$ 460,000$ in 1980. Altogether, an estimated 120 proprietors, family workers, and other employees were supported in whole or part by coastal motels and campgrounds in the County in 1980.

\section{Restaurants}

Over 80 restaurants, grills, dairy bars, and fast food establishments were counted in the coastal area during a field survey in February, 1981. Several are part of or are associated with larger businesses, such as marinas and fishing piers. The largest concentration is found in Calabash, with over 23 establishments counted. The eating-out business is a major industry in the western part of the County, with Calabash-style seafood as the principal attraction.

\begin{tabular}{|c|c|c|c|}
\hline & $\begin{array}{l}\text { Southport- } \\
\text { Oak Island area }\end{array}$ & $\begin{array}{l}\text { South Brunswick } \\
\text { Islands area } \\
\end{array}$ & $\begin{array}{l}\text { Coastal area } \\
\text { total } \\
\end{array}$ \\
\hline All establishments & 32 & 49 & $81^{(1)}$ \\
\hline $\begin{array}{l}\text { No. combined with piers, } \\
\text { marinas, etc. }\end{array}$ & 6 & 8 & 14 \\
\hline $\begin{array}{l}\text { No. fast food, grills, } \\
\text { dairy bars, etc. }\end{array}$ & 12 & 10 & 22 \\
\hline $\begin{array}{l}\text { No. closed or out of } \\
\text { operation in } 2 / 81\end{array}$ & 11 & 29 & 40 \\
\hline $\begin{array}{l}\text { (1) Excludes Shallotte } \\
\text { eating places are highly } \\
\text { of ten questionnaire sur } \\
\text { of the ir business was at } \\
y \text { half of those counted } \\
\text { ding } 60 \text { percent of those }\end{array}$ & $\begin{array}{l}\text { and other non-co } \\
\text { ly sensitive to } t \\
\text { urvey respondents } \\
\text { ttributable to no } \\
\text { were either clos } \\
\text { in the South Br }\end{array}$ & $\begin{array}{l}\text { stal areas of th } \\
\text { urists and seaso } \\
\text { indicated that } 7 \\
\text {-residents. As } \\
\text { d or out of oper } \\
\text { nswick Islands-C }\end{array}$ & $\begin{array}{l}\text { e County. } \\
\text { nal visitors. } \\
5 \text { percent or } \\
\text { shown above, } \\
\text { ation in } 2 / 81 \\
\text { alabash area. }\end{array}$ \\
\hline
\end{tabular}


Receipts averaged an estimated $\$ 1,500$ per seat for restaurants having fewer than 100 seats and $\$ 2,000$ per seat for those having more than 100 seats. Total estimated 1980 sales by all establishments in the coastal area are $\$ 11.9$ million. Average estimated sales per establishment in 1980 were $\$ 147,000$. Calabash restaurants averaged $\$ 340,000$ each and, as a group, accounted for 60 percent of total restaurant sales in the coastal area.

Coastal area establishments generated an estimated $\$ 2.7$ million in labor income and employed an average of 665 persons in 1980. Restaurant worker wages are much lower than other businesses because of the seasonal, part time nature of the business in the area. A wide majority of jobs are part time or are full time for limited periods. Wage and salary employment in 1980 ranged from around 300 during mid-winter months to over 700 in the peak season.

\section{Recreational Attractions}

Aside from six commercial fishing piers, coastal area facilities in 1980 included six golf courses (seven, if the Boiling Springs Lake course is added), five miniature golf courses, two water slides, and several amusement arcades.

Golf Courses. An estimated 125,000 rounds were played on the seven courses in or near the coastal area in 1980. Greens fees, cart rentals, pro shop and food sales, and related expenditures totaled an estimated $\$ 2.3 \mathrm{million}$. This activity generated $\$ 680,000$ in payrolls and employed an annual average of 100 persons. Golf patrons are largely non-residents. Activity peaks in the spring and fall for those courses closest to Myrtle Beach, and during the summer at other courses. Golfing and associated revenues and impacts are expected to increase with continued growth of the retirement population and seasonal visitation in the area.

Miniature Golf. Courses range from modest to elaborate, although less elaborate than many found in the Myrtle Beach area. These facilities rely most heavily on summer visitors, and generally close for several months during the year. Rounds played and revenues vary greatly by facility. For most facilities, gross revenues averaged around $\$ 30,000$, based on approximately 20,000 rounds played in 1980 . A typical local facility will support 1-2 seasonal employees.

Water Slides. These attractions were found in Long Beach and Ocean Isle Beach. Like miniature golf, water slides are oriented almost totally to summer visitors, and are closed for much of the year. A typical facility generated $\$ 125,000$ in revenues and employed 2.2 persons in 1980 . Individual operations will vary substantially if food sales and other attractions are included. 


\section{SEASONAL VISITATION AND ITS IMPACTS}

County-level tourist expenditure estimates developed by the State presently are based on receipts from hoteis, motels, and other commerical places of accommodation. This technique is seriously misleading for Brunswick County, in which 90 percent of overnight visitor capacity is in seasonal cottages and apartments. Rentals of these units, in all but a few cases, are not taxed as retail sales; thus, the State method uses a much smaller data base for expanding to total estimated expenditures.

Because of shortcomings in the State method, another procedure was utilized, which takes local characteristics into account. Visitor expenditures were developed from estimates of the number of visitor days spent in the area and assumptions of per person per day expenditures by overnight and day visitors.

\section{Visitation}

Overnight visitors spent an estimated 3.3 million visitor days in the coastal area in 1980. These included cottage and apartment renters and guests, nonresident owners and guests, and motel and campground users in the beach communities and in other sections of the coastal area. Day visitors spent another 1.2 million visitor days in the area, for a total of $4.5 \mathrm{million}$ visitor days. A visitor day is defined as a day or part thereof spent in the coastal area by a non-resident, during which time an expenditure for goods and/or services is assumed. Not included in these estimates are travelers passing through on U.S. 17, unless they stopped for services in the coastal area.

An estimated 1.5 million visitor days were spent in the Southport-Oak Island area, including 1.2 million by overnight visitors. The South Brunswick Islands-Calabash area generated an estimated 3.0 million visitor days, of which 2.1 million were by overnight visitors. Another 0.9 million visitor days were spent by day visitors in this area, attracted mainly by Calabash restaurants.

Visitor day estimates for overnight visitors reflect the following number of visitor days per unit.

\section{Type of Accommodation}

Visitor Days Per Unit

Seasonal cottages/apartments rented through local realty firms-beach communities only $725-765$

Seasonal cottages/apartments used or rented directly by owners-beach communities 


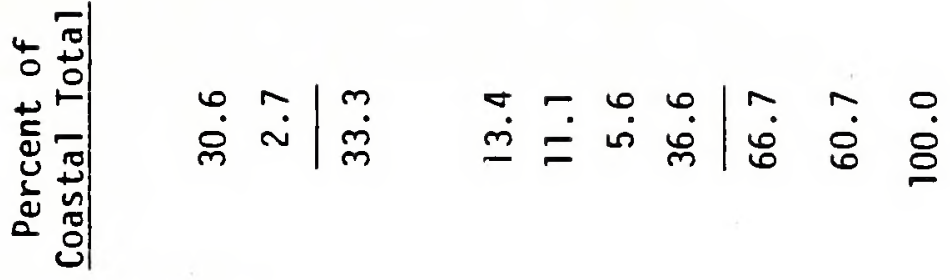

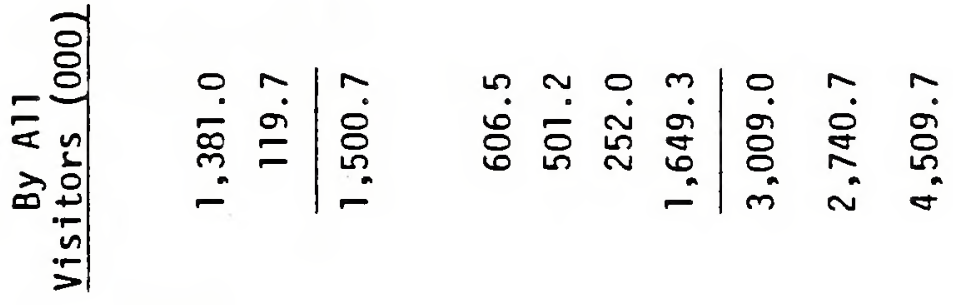

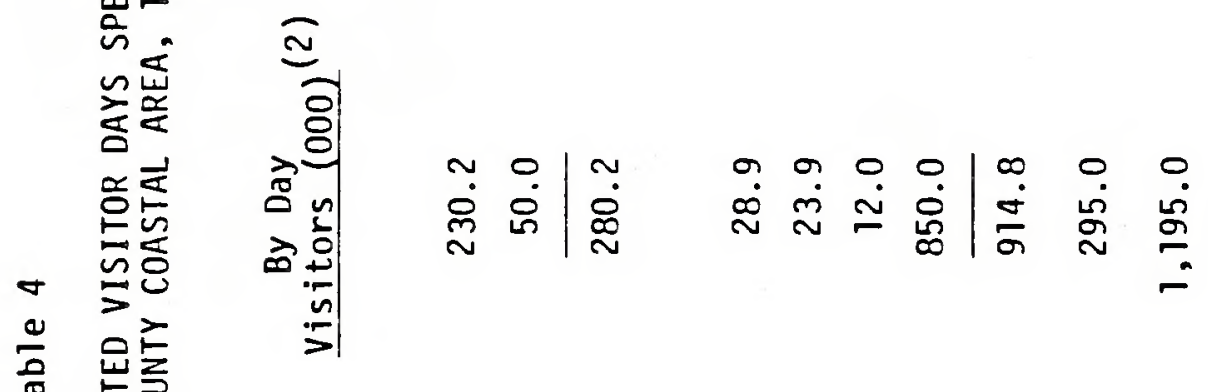

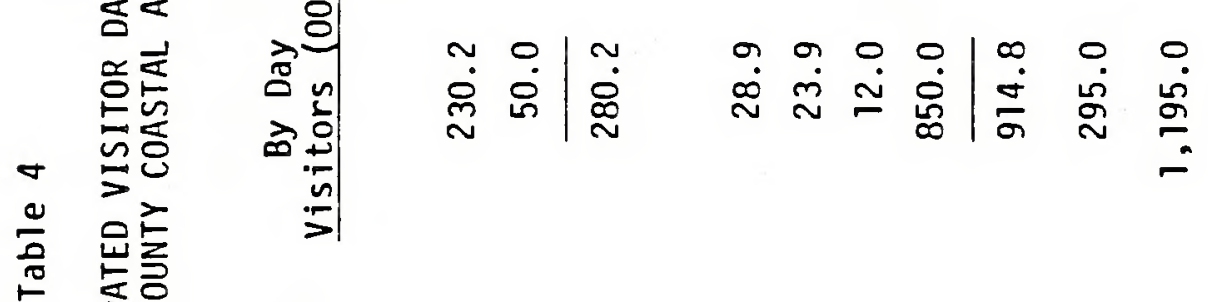

$$
\begin{aligned}
& \text { 感 I } \\
& \text { 高足 }
\end{aligned}
$$

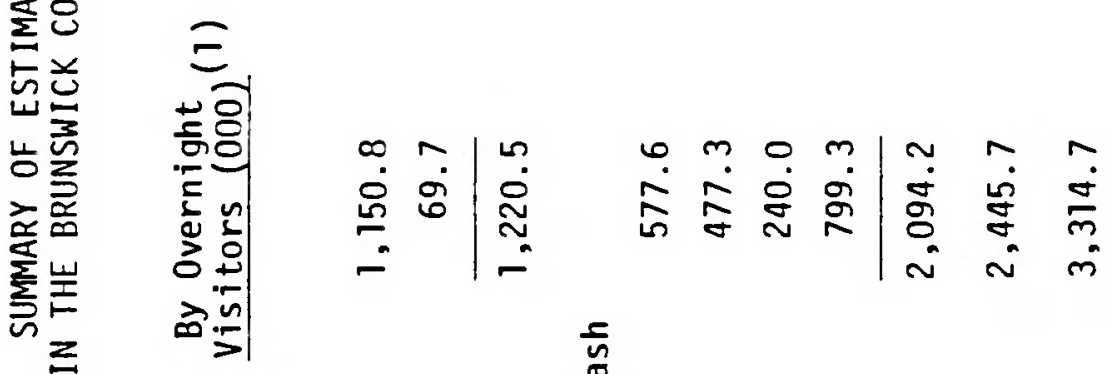

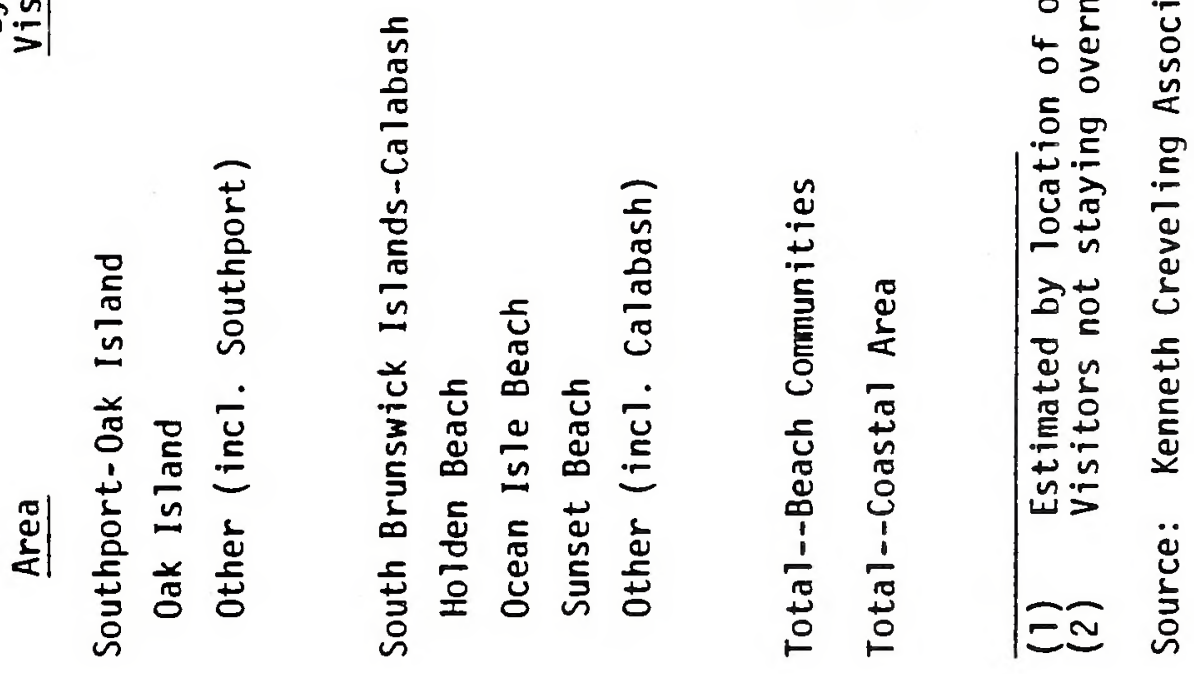

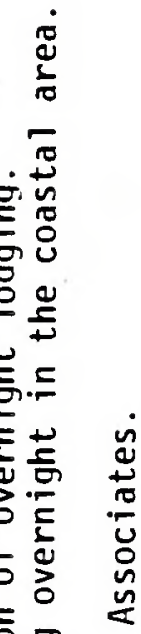

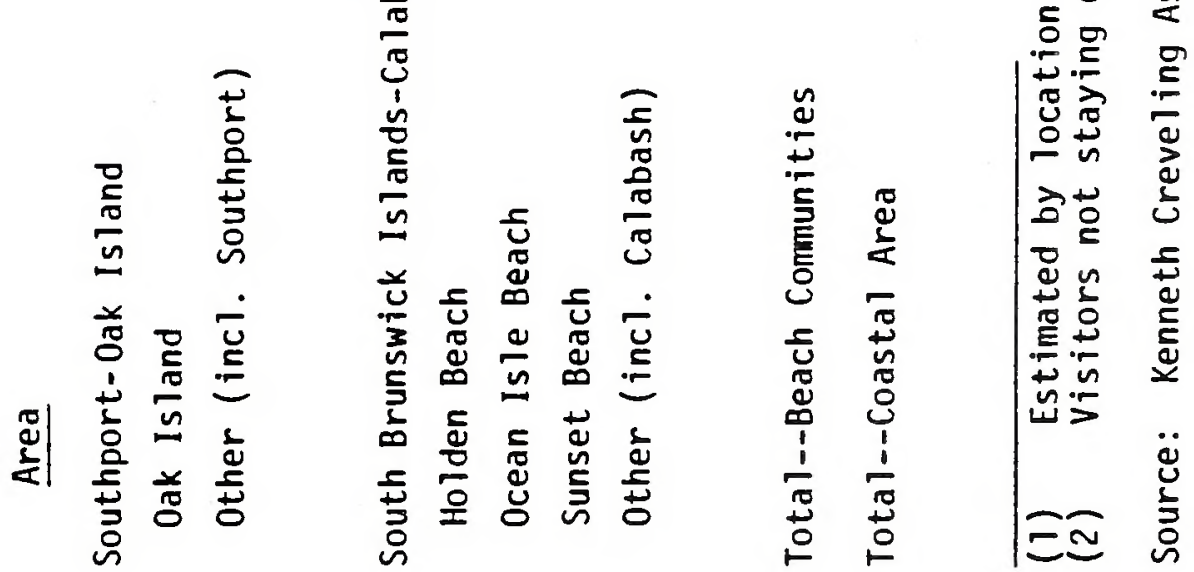


Seasonal homes used or rented directly by owners--mainland

Motels--al1

Campgrounds--all

Note: These indicies were calculated from estimates of the numbers of visitor days and numbers of units of each type.

\section{Expenditures}

There are three types of local spending by visitors to the Brunswick County coastal area, as follows:

- Normal vacation and trip-related expenditures for lodging, food, fuel, recreation, and related items.

- Home-related expenditures by non-resident owners of seasonal cottages and apartments on such goods as furniture, equipment, and supplies and on services associated with maintenance and repair of seasonal homes.

- Other expenditures, usually by non-resident owners, related to the purchase and servicing of recreational equipment, including boats and motors, and other capital goods.

Day and overnight visitors to the coastal area in 1980 spent an estimated $\$ 48$ million on normal vacation and trip-related items, which constitute the major share of expenditures by non-residents. Of this total, however, only $\$ 37$ million was directly spent or retained in the County. This includes $\$ 28$ million by overnight visitors and $\$ 9$ million by day visitors.

Seasonal cottage and apartment rental expenditures accrue almost entirely to non-resident owners and, thus, leave the County. Some returns to the County, however, in the form of commissions paid to local realty firms, purchases of furnishings and other home-related goods, and expenditures for maintenance and repair services. In addition to exporting rental expenditures, some portion of spending by overnight visitors occurs on side trips to nearby areas, such as Myrtle Beach.

Estimates of total vacation and trip-related expenditures for 1980 are based on the following per capita per day spending assumptions applied to estimated numbers of visitor days for each category of visitor: 
Type of Visitor

and Accommodation
Assumed Expenditures

Per Person Per Day (\$)

Overnight Visitor

Seasonal cottage/apartment--

beach communities, rented locally

$17.00^{(1)}$

Seasonal cottage/apartment--

beach communities, other

$9.00^{(2)}$

Seasonal home--mainland

5.00

Mote $1--a 11$

22.00

Campground--a 11

9.00

Day Visitor

7.50

(1) Includes rent (averaged out at $\$ 7.00$ per person per day)

(2) Rents are negligible.

Vacation and trip-related expenditures made in the County by coastal area visitors are distributed among the following categories:

\begin{tabular}{lcc} 
Category & $\begin{array}{c}\text { Estimated 1980 } \\
\text { Expenditures } \\
\text { (S millions) }\end{array}$ & $\begin{array}{c}\text { Percent of } \\
\text { Total } \\
\text { Expenditures }\end{array}$ \\
\cline { 2 - 2 } Food (markets, restaurants, etc.) & 21.6 & 58.4 \\
Transportation (fuel, etc) & 3.4 & 9.2 \\
Lodging (motels/campgrounds) & 2.3 & 6.2 \\
Recreation (golf, fishing, etc.) & 5.7 & 15.4 \\
Other (souvenirs, gifts, etc.) & 4.0 & $\underline{10.8}$ \\
Total--All Categories & $\underline{37.0}$ &
\end{tabular}

Fifty-eight percent of the visitor dollar spent in the County in 1980 went for food, which accounts for the disproportionate shares of retail sales by grocery stores/markets and by eating/drinking places in the County. Spending for auto services, lodging (other than seasonal cottage/apartment rentals), recreation, and other goods and services were relatively minor by comparison. 
With the addition of seasonal cottage/apartment rentals, home furnishings and housekeeping-related purchases by non-resident owners, and other capital goods purchases, total spending by visitors to the coastal area probably exceeded $\$ 50$ million in 1980 .

\section{Direct Economic Impacts}

An estimated $\$ 37.0$ million of vacation and trip-related expenditures in the County in 1980 by coastal area visitors had the following impacts:

- Generated $\$ 6.3$ million in local payrolls.

- Supported approximately 1,165 average annual jobs.

- Supported in whole or part 275-300 local businesses.

These payroll and employment impacts are inclusive of those previously and individualiy assessed for fishing piers, charter and head boats, and marinas, and for motels and campgrounds, restaurants, and recreational attractions. Not reflected in the above estimates of payrolls and employment are impacts from the construction and rental of seasonal cottages and apartments, from local purchases of housing-related goods and services by non-resident owners of seasonal homes, and from local purchases of out-of-the-ordinary capital goods and services by visitors, such as the purchase and overhaul of boats and motors.

Coastal area visitor expenditures accounted for 11 percent of all 1ocal wage and salary employment. Average annual wages for jobs in the travel/recreation sector, however, were less than half of the countywide average for all jobs, because of the seasonal nature of employment related to travel and recreation.

Money brought into the area by visitors turns over several times, generating additional income and supporting more jobs with each successive turnover. Assuming a multiplier of 1.5 , a direct expenditure of $\$ 37.0$ million by visitors will generate additional incomes of $\$ 18.5 \mathrm{milli}$ ion in the area, as expenditures are made by businesses and employees. 


\section{OIL SPILL SOURCES, RISKS, AND IMPACTS}

Coastal areas are susceptible to crude $0 i 1$ and petroleum product spills from a variety of sources. These include refineries, marine terminals, vessel traffic, and offshore oil exploration and development. Sources and risks of potential spills in the Brunswick County area, and vulnerabilities of local natural resources and economic activities to spill damage are summarized herein.

\section{SOURCES OF POTENTIAL SPILLS}

Announcement of plans in 1979 by the Brunswick Energy Company (BECO) to construct a 150,000 barrel-per-day refinery on the Cape Fear River triggered expressions of concern over the impact of oil spills on the region's natural resources and the economic activities which those resources support. For the present, the refinery is no longer an oil spill issue, plans having been withdrawn by BECO in May 1981. Yet, other sources of spills continue to exist, as was vividly illustrated by the spill which reached Dare County beaches that same month. That spill resulted from the collision of two cargo ships, with a reported 40,000-50,000 gallons of fuel oil reaching shore and spreading along several miles of beachfront. One year earlier (May 1980), a 644-foot tanker bound for Wilmington and carrying a reported 300,000 barrels of fuel oil nearly sank in waters near Frying Pan Shoals some 26 miles from the mouth of the Cape Fear River. Fortunately, a potential spill of major proportions was averted, but the incident illustrates the susceptibility of coastal areas to oil spill dangers.

Principal sources of oil spills which would affect coastal resources and economic activities in Brunswick County are marine transportation, particularly vessels transporting $0 i 1$ and oil products to/from the port of Wilmington and along the coast, and offshore exploration and development. Trends of marine commerce and the status of OCS activities in the region are reviewed in this subsection.

\section{Marine Transportation}

During the nine-year period from 1969 through 1977, crude $0 i 1$ and petroleum products moving through the port of Wilmington averaged nearly 4,800 tons. Only four percent was crude oil. The remainder was composed of a variety of refined products, chiefly residual fuel oil and gasoline. An estimated 85 percent of total annual tonnage of $0 i 1$ and $0 i 1$ products was inbound from foreign and other U.S. ports.

Shipments increased rapidly during the early 1970s, peaking at over 6,500 tons in 1973. Foreign crude $0 i 1$ interruptions and resultant changes in domestic production and demand caused a sharp decline in shipments, which hit bottom in 1975. Shipments were up again in 1976 and 1977, but were well below the 1973 high. 
Fluctuations in shipments through Wilmington have been largely the result of swings in imports of crude oil and refined products from foreign ports. Meanwhile, shipments from other U.S. ports followed an upward trend in most years, in response to growing regional demand for refined products. Imports were more than half of all shipments into Wilmington in the early 1970s, but slipped to around 30-35 percent by 1975-1977.

Fluctuations in tank ship and tank barge traffic paralleled the ups and downs in $0 i 1$ and oil product shipments, peaking in 1973 and bottoming-out in 1975. Between 1972 and 1977, tank ship traffic averaged 750 arrivals and departures, or approximately two per day. Roughly 350-400 of these deep-draft ships serviced local petroleum terminals. Tanker barge traffic averaged 1,550 movements during this period, or approximately four daily. Tank ship traffic has been a small percentage of overall ship traffic, averaging 5-6 percent of the total. Tank barge traffic, meanwhile, has averaged 40-50 percent of total barge traffic on the River.

Tank ships calling at the port of Wilmington between 1972 and 1977 were relatively small by contemporary standards. U.S. Army Corps of Engineers data indicated that only 24 percent had drafts of 35 feet or more. Most ships were probably less than 25,000.tons in deadweight capactity (DWT), and average cargos appear to have been much smaller than that.

\section{Offshore 0il Exploration and Development}

The Federal government's outer continental shelf (OCS) oil and gas leasing program permits commercial exploration and development of suspected undersea oil and natural gas deposits in coastal waters of the United States. Several lease sales have been held and are planned under the aegis of the U.S. Department of the Interior. One such lease sale, No. 56, involves offshore waters extending from the Outer Banks in North Carolina to southeastern Georgia.

Lease Sale 56 includes 286 tracts covering some 2,500 square miles. Tracts range from 15 to 115 miles from shore and lie in waters from 60 feet to over 4,000 feet deep. An initial sale was held in August, 1981. Only 54 tracts were bid on and 47 of these were actually leased. A re-offering sale is planned for June, 1982 for tracts on which no bid were received initially and those others which were bid on but not accepted for lease. Bid and lease activity was concentrated in clusters of tracts at the edge of the continental shelf (approximately the 600-foot contour) and in deeper waters offshore of the North Carolina coastline and in shallow waters near Savannah, Georgia. Those tracts nearest to Brunswick County lie in deep waters 100 or more miles southeast of Cape Fear.

If oil is discovered in commercial quantities, means of transportation to land will have to be decided. Under ordinary circumstances, pipelines may be preferred over tankers because of their comparatively safer operational history, among other factors. Pipelines are the principal facilities for 
transporting oil from offshore fields in the Gulf of Mexico. Pipeline transportation to nearby coastal areas may be less feasible, however, if plans for proposed refineries in the region are withdrawn, as in the case of the BECO refinery. On the other hand, an offshore oil find may boost industry plans for development of coastal refineries.

\section{SPILL PROBABILITIES AND RISKS}

\section{Vesse1-Related Spil1s}

December, January, February, and June were the leading months for vesse1related spills over 1,000 gallons along the Atlantic coast from 1975 through 1980. Spills over 1,000 gallons are regarded as major spilis. The winter season (December-March) accounted for 46.5 percent of such spills over this six-year period. For spil1s over 100,000 gal1ons, 71 percent occurred during this four month season. This data iliustrates the relatively greater hazards associated with the colder months, when weather and sea conditions are generally more adverse and long-lasting. These adverse conditions increase risks of ship groundings and collisions and faulty bulk transfer operations at sea moorihgs and marine terminals.

The coastal region extending from the Outer Banks to the vicinity of Hilton Head Island, South Carolina, has had a very limited history of spills over 1,000 gallons from 1975 to 1980 . Only eight such spills were recorded during this six-year period, the largest of which was only 8,700 gallons. No monthly or seasonal patterns are discernible from this limited data.

Altogether, an estimated 310 vessel-related spills of all sizes were recorded between 1975 and 1980 in this coastal region. Vessel-related incidents peaked in 1978 with 76 spills. After that, the number dropped significantiy to only 30 vessel-related spills in 1980. Spills over 1,000 gallons were 2.6 percent of al1 vessel-related incidents during the six-year period.

A BECO study of oil spill impacts included estimates of the probabilities of spills resulting from tank barge and tank ship accidents -- collisions, groundings, rammings, etc. -- and from normal vessel operations, such as ballast tank cleaning, cargo loading/off-loading, etc.

Probabilities of accident-caused spills of any size were conservatively estimated at 5.22 per 100,000 trips (one-way movements) for tank barges and 36.4 spills per 100,000 port calls (two-way movements). Return intervals for non-catastrophic spills were estimated at 8.6 years for tank barges, 9.1 years for product tank ships, and 200.2 years for crude oil tank ships without the BECO refinery. A return interval is the statistical average length of time between spills. For catastrophic spills, return intervals were estimated to be at least ten times greater than those for non-catastrophic spills. The return interval for a catastrophic spill from a crude oil tanker, for example, was estimated at 2,123.1 years. 
Study findings suggest a negligible risk of accident-caused spills from barges and ships transporting oil and oil products to/from the port of Wilmington. Spills associated with two other types of vessel movements, however, do not appear to have been included in this BECO study.

- Spills of cargo and fuel related to offshore accidents involving tank ships not calling at Wilmington, but merely passing by en route to/from other ports.

- Spills of fuel related to accidents involving other cargo ships.

These other accident-related spill sources, plus those associated with other vessel operations, tend to increase overall risks to the Brunswick County coastline.

\section{OCS-Related Spills}

Spill probability estimates were made by the U.S. Bureau of Land Management (BLM) for OCS Lease Sale 56. Only six spills over 1,000 barrels $(42,000$ gallons) were predicted over a 25 to 30 -year production life of the sale area, including both platform and transportation-related spills. In making this prediction, the BLM considered Gulf of Mexico OCS experience with pipeline leaks and breaks, blowouts, fires and explosions, storm damage, and ship-platform collisions. Probabilities that one or more such spills will reach the Brunswick County coastline are summarized on the following page.

\begin{tabular}{|c|c|c|c|}
\hline \multirow[b]{2}{*}{ Source of Spill } & \multicolumn{3}{|c|}{ Percent Probability } \\
\hline & 3 days & 10 days & 30 days \\
\hline Platform & 0 & 0 & 1 \\
\hline Transportation Route & 2 & 3 & 4 \\
\hline A11 & 1 & 1 & 1 \\
\hline
\end{tabular}

The only clusters of tracts for which a probability of platform spills reaching the Brunswick County coastline was determined, however, are those within which no bids. were made during the initial sale. Greater probabilities were associated with transportation-related spills, but the concellation of BECO refinery plans lessens the significance of Wilmington as a crude $0 i 1$ receiving port, either by ship or pipeline. 


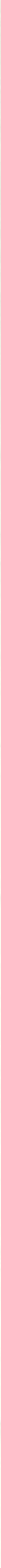




\section{IMPACT OF POTENTIAL SPILLS}

Information thus far presented in this Section points to very low probabilities of the occurrence of damaging oij spills. Yet the history of the past 10-15 years has shown that $0 i 1$ spills of major proportions can occur at anytime, anywhere -- occasionally with catastrophic effects. Vivid recent examples of unpredictible spills of unprecedented size include the Amoco Cadiz tanker spill in 1978, which affected 135 miles of French coastline, and the IXTOC-I offshore platform blowout in 1979, which impacted hundreds of miles of Mexican and Texas coastline. These incidents involved spills of approximately 65 million and 130 million gallons of crude $0 i 1$.

The environmental effects of oil spills on marine plant and animal life have been subjects of a great many research efforts, most precipitated by major oil spills in the U.S. and abroad. Even so, actual cause-effect relationships have not been thoroughly researched or conclusively shown, because of the limited number of major incidents and great variability in their characteristics.

Significantly less is known about economic impacts, as research has focused almost entirely on environmental effects. Measurement of tangible impacts, in most areas, is precluded by an absence of appropriate data on ecomomic conditions before and after a spil1. Moreover, there is very little research, if any, on the effects of a spill incident on the perceptions and resultant travel behavior of potential visitors to an affected area. Therefore, effects on local coastal resources and economic activities are discussed in qualitative terms.

Coastal areas are vulnerable to two types of spills:

- Acute - Spills of large size which occur rarely, but can be devastating to coastal marine 1 ife, recreational resources, and economic activities.

- Chronic - Small spills which occur frequently and which are individually minor and manageable, but can cause environmental and economic damage after repeated incidents.

Acute oil spills draw regional, national, or world attention when they occur, and normally attract large-scale commitments of financial and human resources for containment and cleanup operations. Chronic spills, however, can be more insidious, since their recurrence over time tends to degrade the amenities and alter perceptions of the affected area. In most cases, areas jeapordized or impacted by acute spills return to normal in a relatively short time, with the knowledge that such spills are rare and unlikely to recur. 
Vessel-Related 0il Spill Scenarios

A number of oil spill impact scenarios were defined in the BECO oil spill impact study in terms of the cause, location, size, and duration of spills of different materials. These scenarios cover a range of possibilities and impacts, including crude and product tanker groundings on Frying Pan Shoals and groundings and collisions at several locations in the Cape Fear River.

Spills from vessels running aground on Frying Pan Shoals were shown to stay at sea, moving off to the northeast or southwest with prevailing winds. Nearby coastal areas would not be impacted. Despite a greater probability of accident-caused spills occurring during times when wind and sea conditions are not prevailing (i.e., typical), the BECO study conclusion is considered reasonable for the Brunswick County coastline. Winds and ocean current data suggest an extremely low probability of an alignment of environmental conditions which would push spills occurring on Frying Pan Shoals in a northwesterly direction towards Brunswick County beaches. Instead, such spills appear to pose a much greater threat to beaches in New Hanover County and areas farther north. Brunwick County beaches, on the other hand, appear to be more threatened by potential spilly south of the Cape Fear arch.

Spills occurring in the Cape Fear River would affect different portions of the estuary, depending on location, size, material spilled, and tidal direction. Analyses were made by BECO for spills of crude oil, light distillate, and gasoline averaging in the order of 5,000 barrels (over 200,000 gallons). Spills occurring farther upriver would have a progressively smaller impact on the coastal area. The Southport waterfront, a portion of the Caswell Beach oceanfront, and the west-facing beach on Bald Head Island would be impacted by lower estuary spills. Nearby tidal marshes would also be affected.

\section{Potential Impacts on Economic Activities and Recreation}

Commercial Fishing. Fishermen may be particularly hard hit by a major spill in coastal waters because of local dependency on species most vulnerable to impacts--shellfish. Not only are reductions of catch possible, but affected fish and shellfish may become tainted and lose market value. Moreover, trawls, nets, and other fishing gear can become oiled and rendered temporarily or permanently useless.

Many dealers and packing and processing plants, would be able to continue operations by obtaining catch from areas unaffected by spills. Local restaurants should be relatively unaffected by reductions in or damages to local fisheries, since they too are able to obtain supplies from other areas.

Recreational Fishing and Boating. Pier and surf fishing dominate recreational fishing in the County. A beach spill during the season can have a significant temporary impact on these activities by driving fish away 



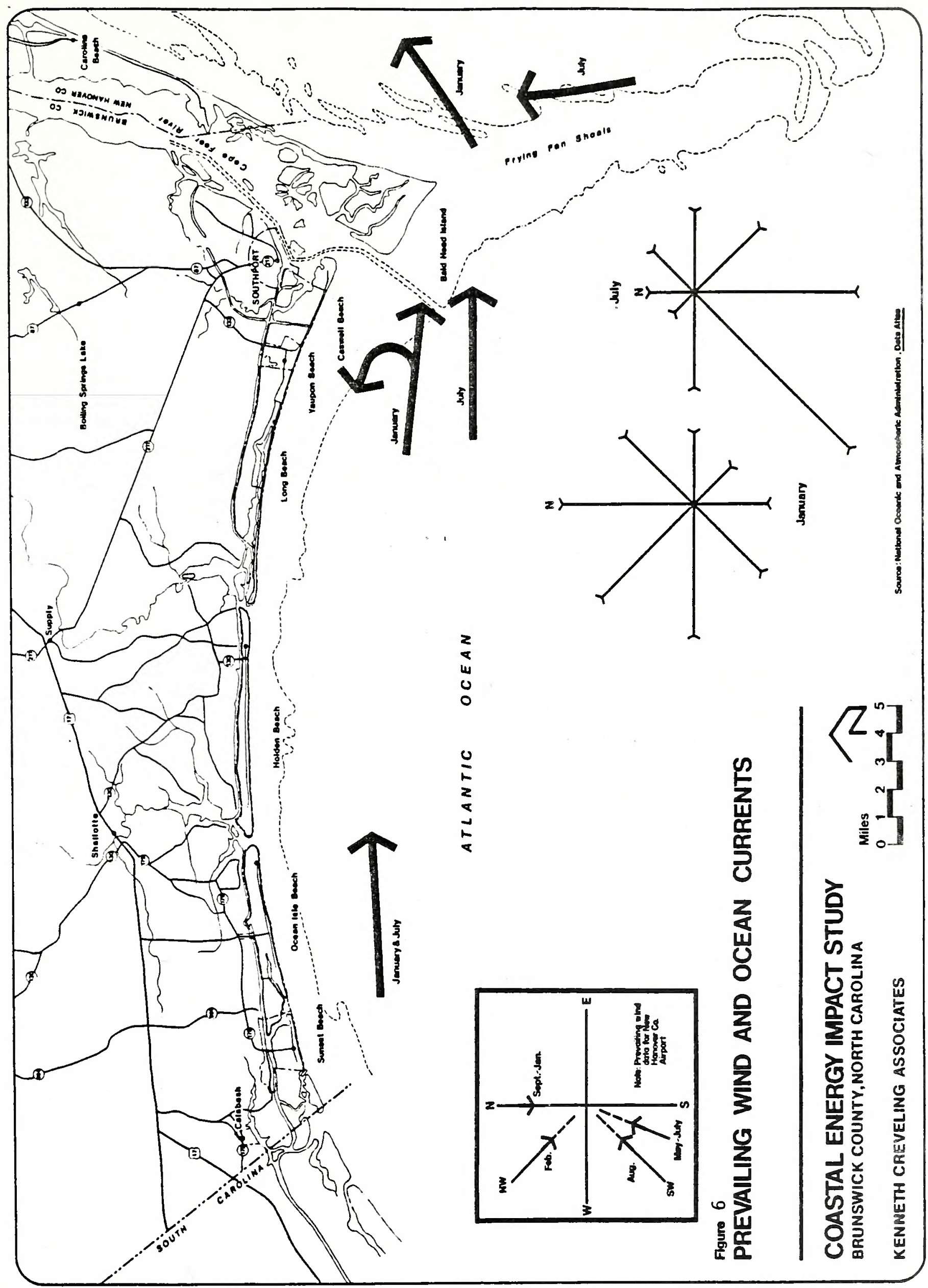



from the affected area, fouling lines and nets, and creating generally unpleasant conditions. More long-lasting effects can occur depending on the extent to which fish are kept away by oil mixed with subtidal sands and clinging to pier pilings.

Ocean spills should not significantly affect boating and deep sea fishing, which could avoid impacted waters. This includes charter and head boats and other offshore fishermen using private boats. On the other hand, a spill in inside waters could have significant adverse and long-lasting impacts on boating. Unless contained or diverted, oil could find its way into marinas, launch areas, and residential lagoons. This would limit access, stain boats, and inhibit boating and boat-related fishing.

Seasonal Visitation. Beaches are the principal attractions for visitors to the County's coastal area. Regardless of actual spill conditions, potential visitors may cancel travel plans, rather than face an uncertain trip and vacation. Similarly, trips and vacations may be cut short if spills occur when visitors are in the area. However, the extent and duration of visitor loss is dependent on so many variables as to defy estimation beforehand.

With the probability of major spills being greater during winter months, incidents are least likely during the main tourist seasons in most beachoriented areas of the Atlantic coast. Beach spills occurring during winter months generally will be gone by the summer tourist season. However, a large winter spill may give pause to those planning summer vacations in areas such as Brunswick County, where seasonal cottage and apartment rentals tend to be made months in advance. This points to the need to counter any adverse publicity, so that conditions which may in fact be localized or temporary are not perceived by potential visitors as widespread and long-lasting.

Coastal Businesses. Businesses most dependent on seasonal visitors, such as motels, campgrounds, and fishing piers, are those most susceptible to economic loss from oil spills. Moreover, many seasonally-oriented businesses are marginal, and a significant ioss of patronage could result in some failures and closures.

Investment and construction. Investment in new retirement and seasonal housing and the related construction trades are less likely to to impacted by a single acute oil spill than by a succession of smaller incidents, which tend to degrade coastal amenities over a long period of time. However, without major increases in vessel traffic and offshore drilling in the Cape Fear area relative to competitive coastal recreation/tourist areas, long term impacts from chronic spills are not significant concerns. 


\section{RECOMMENDATIONS}

Recommendations from this study are concentrated in two areas, as follows:

- Additional data and research needed to improve abilities to measure and assess economic impacts of potential $0 i 1$ spills.

- Local contingency planning to supplement Federal and state responsibilities in oil spill containment and cleanup.

\section{DATA AND RESEARCH NEEDS}

$0 i 1$ spill impact prediction and assessment can benefit from additional or improved data sources and research in the following key areas:

- Perceptions and behavior of user groups, such as seasonal home buyers and tourists, with respect to coastal recreation areas affected by acute and chronic spills.

- Comprehensive baseline economic data for such areas, from which measurements and assessments of impacts can be made after spills take place.

- Measurements and assessments of the extent, duration, and types of changes in economic activities which have occurred over time after actual major oil spills and, in the case of chronic spills, after repeated incidents.

Only until sufficient research fingings and data are available are correlations between oil spill circumstances and characteristics and user behavior and economic impacts likely to become more apparent, predictable, and quantifiable than at present. This Brunswick County study has some major 1imitations in this regard. Principal benefits, however, are: (1) the development of profiles of important local economic activities in the coastal area from which impacts of potential future oil spills can be more easily measured and assessed; and (2) the provision of information to aid state and local officials in the establishment of policies and priorities for coastal and offshore development and oil spill management.

Since oil spills can impact any section of the North Carolina coastline, responsible state agencies should initiate or sponsor basic research on coastal economic activities and user groups to the degree not possible in this study. Specific needs include those outlined below.

\section{Economic Activities}

Additional surveys and assessments of the following economic activities and businesses are recommended: 

- Commercial fishing--numbers of fishermen, dependency on local fisheries and on fishing, income characteristics.

- Commercial fishing-oriented businesses, such as retail outlets, wholesalers, and packing and processing plants--linkages to local fishermen and catch, distribution channels, revenues and operations, payrolls and employment.

- Boating-oriented businesses, such as marinas, marine sales firms, and boat builders--dependency on residents and non-residents, revenues and operations, payrolls and employment.

- Amusements and recreation services, such as fishing piers, charter/ head boat services, and golf courses--usage, dependency on nonresidents, revenues, and operations, payrolls and employment.

User Groups

Basic surveys and assessments of the following user groups are recommended:

- Coastal tourists and vacationers, such as day visitors, cottage/ apartment renters, and motel/campground users--type and amount of local expenditures, origin, party size, reactions to oil spills.

- Non-resident owners of properties and second homes--home origin, usage (by owners, guests, and renters), costs of operation, income (from rentals), local spending for household-related goods and services, reasons for ownership (e.g., income, investment, retirement, etc.), reactions to oil spills.

- Recreational fishermen--mode of fishing, origin, expenditures, reaction to oil spills.

Expenditure data would permit verification, modification, and expension of assumptions used in this study. Information on visitor origin would aid in assessing the competitive positions of various coastal sections and in targeting promotional efforts aimed at overcoming adverse publicity. And, information on the probable reactions by visitors and non-resident owners to oil spills would greatly improve abilities to estimate potential economic losses.

\section{CONTINGENCY PLANNING}

Planning in anticipation of an oil spill is the key to maximizing containment and cleanup operations and minimizing adverse impacts if and when a spill occurs. Federal regulations give the U.S.Coast Guard and the U.S. Environmental Protection Agency national responsibilities in oil spill prevention and management. In each of several regions, a designated On-Scene 

Coordinator is responsible for coordinating and documenting all activities and circumstances related to oil spills. The ranking officer of the U.S. Coast Guard office in Wilmington is the On-Scene Coordinator for oil spills affecting the Brunswick County coastal area. State activities in oil spill management are the responsibility of the Department of Natural Resources and Community Development (NRCD), which works closely with Federal officials.

In general, the discharger has primary responsibility and legal liability for an accidental or intentional discharge of oil in coastal waters. The major roles of Federal and state governments are to identify the discharger, supervise cleanup operations, and to assume control of cleanup where the discharger or spill source is unknown. The State of North Carolina does not have physical response capability and relies on the Federal On-Scene Coordinator to mobilize equipment and personnel needed.

\section{Local Contingency Planning}

Although responsibility rests primarily with higher levels of government local governments can make a significant contribution to the total response effort in the first few hours after a spill, as it may take several hours for Federal and state governments to organize and mobilize on-scene activities. In many instances, if a county or town government had the capability to deal with a spill situation, it could provide a first line of defense in protecting sensitive resources from a spill.

Contingency planning by or on behalf of Brunswick County and its constituent municipalities should accomplish the following:

- Establish procedures for reporting and responding to spills.

- Assign and train designated local personnel.

- Inventory available containment and cleanup equipment and purchase supplemental equipment as needed.

- Establish policies and priorities for use of local personnel and equipment until responsible Federal and state authorities are on the scene.

- Identify proper containment and cleanup techniques and procedures to be used in relation to the resource threatened or impacted and the material spilled.

- Determine local sites or facilities for the disposal of captured oil and sand/oil mixtures.

In the case of offshore spills, there is general agreement among contingency planners that tidal inlets should have priority for protection over beaches, to safeguard marshes and important or fragile fishery nursery and harvest 

areas. Recognizing the difficulty in protecting miles of beachfront against oil spills driven by winds and waves, contingency planning for beach spills should focus instead on cleanup.

For spills in or threatening estuaries and other inside waters, priorities must be established between and among natural resources and man-made features, such as marinas and residential lagoons, where personnel and equipment are limited and more than one resource or feature is threatened.

It is recommended that an oil spill contingency plan for Brunswick County be developed with assistance from the NRCD in the following four phases:

Phase 1. This phase would involve the assembly of local information needed to plan a spill response. An inventory of equipment and support services readily available for use should be prepared. Maps identifying vulnerable resources and features should be compiled to guide deployment of personnel and equipment. Note: Much of this information is already available; some has been compiled in this study.

Phase 2. Next, a local response organization and procedural format should be developed and local résponse teams designated, using local police, fire, and civil defense personnel as the base. The nature and responsibilities of local response personnel and procedures should be defined in relation to Federal and state responsibilities. Emergency service numbers should be established to facilitate local reporting of oil slicks and other evidence of spills.

Phase 3. This third phase would identify techniques and detail procedures for local involvement in containment and cleanup operations.

Note: A review or applicable techniques and procedures is included in this study.

Phase 4. Under this last phase of the plan, local response teams would be trained in the handling of $0 i 1$ and associated materials in various stages of containment and cleanup. Each team should also be equipped with communications gear, truck, boat, boom, and sorbent materials, to the extent that such equipment is not readily available.

The contingency plan should place emphasis on having equipment and capacity on hand to contain spills occurring in or reaching the inlets, estuaries, and Intracoastal Waterway, until such time as Federal and state authorities can reach the scene and take over operations. Removal and disposal of oily material resulting from beach spills should also be addressed in the plan.

The need for such a plan in Brunswick County is not a major priority at the present time. If and when offshore oil lease areas show evidence of commercial yields or plans for a new Cape Fear River refinery re-emerge, however, the need for contingency planning at the local level will become much more apparent. 



\title{
Overcoming Adverse Publicity
}

In coastal areas affected by major spills, adverse publicity can sometimes be more damaging than spills themselves. This may be particularly true for the North Carolina coast, where most beach communities are oriented to family vacations and plans to visit are made well in advance. Word of a large spill, whether or not actual damage was severe or long-lasting, may cause some families to cancel reservations and vacation elsewhere or reduce their stay in the affected area. Those who visit Brunswick County travel considerable distances. Many are also repeat visitors who might shift their travel habits and loyalties to other coastal areas offering similar, but spill-free, amenities.

Actions to overcome adverse publicity fall mainly on the private sector-chambers of commerce, rental agents, and operators of local facilities. If certain beaches are temporarily impacted by spills, other attractions in the area should be promoted and arrangements made for use of nearby beaches. In the event of a major spill, the Southport-Oak Island Chamber of Commerce and the South Brunswick Islands Chamber of Commerce should initiate and coordinate fact sheets distributed by rental agents, news releases, travel articles, and cooperative arrangements.

The North Carolina Travel and Tourism Division can supplement local efforts by providing information through its media and distribution channels, as well as providing emergency funds needed for stepped-up promotion at the local level.

\section{0il Spill Notification Directory}

To initiate response to an oil spill situation, one of two numbers may be called by local officials and citizens in the following order:

\author{
PRIORITY 1 CALL: U. S. Coast Guard (USCG) \\ Captain of the Port-Wilmington (COTP) \\ USCG COTP - Wilmington \\ $919 / 343-4881$
}

PRIORITY 2 CALL: If the above number cannot be reached, then the following number should be called:

U. S. Coast Guard National Response Center $1-800 / 424-8802$

Spill sighting may also be reported to the Wilmington office of the $N$. C. Department of Natural Resources and Community Development (NRCD):

919/762-3394. 
Residents and businesses may also call the following local numbers, to trigger response actions by local governmental officials. Upon receiving such calls from local residents, responsible officials should also immediately notify the Coast Guard and NRCD.

$\begin{array}{lll}\text { Location } & \begin{array}{c}\text { Telephone Number } \\ \text { to Call }\end{array} & \end{array}$

When notifying Federal, state, and local officials of a spill or potential spill, the following information should be provided as completely as possible:

- Date and time of spill or sighting.

- Precise location.

- Type of material involved (if known).

- Quantity observed or discharged (large, small, etc.).

- Reason for and source of spill (if known).

- Proximity of spilled material to vulnerable resources/features.

- Actions (if any) being taken at the scene to contain/remove the material.

- Your name and telephone number in case further information is necessary. 
1. Hauser, E. W., P. D. Cribbins, P. D. Tschetter, and R. D. Latta. Coastal Energy Transportation Needs to Support Major Energy Projects in North Carolina's Coastal Zone. CEIP Report 非. September 1981. \$10.

2. P. D. Cribbins. A Study of OCS Onshore Support Bases and Coal Export Terminals. CEIP Report 非2. September 1981. \$10.

3. Tschetter, P. D., M. Fisch, and R. D. Latta. An Assessment of Potential Impacts of Energy-Related Transportation Developments on North Carolina's Coastal Zone. CEIP Report 非. July 1981. \$10.

4. Cribbins, P. S. An Analysis of State and Federal Policies Affecting Major Energy Projects in North Carolina's Coastal Zone. CEIP Report \#4. September 1981. \$10。

5. Brower, David, W. D. McElyea, D. R. Godschalk, and N. D. Lofaro. Outer Continental Shelf Development and the North Carolina Coast: A Guide for Local Planners. CEIP Report \#5. August 1981. $\$ 10$.

6. Rogers, Golden and Halpern, Inc., and Engineers for Energy and the Environment, Inc. Mitigating the Impacts of Energy Facilities: A Local Air Quality Program for the Wilmington, N. C. Area. CEIP Report 非6. September 1981. \$10.

7. Richardson, C. J. (editor). Pocosin Wetlands: an Integrated Analysis of Coastal Plain Freshwater Bogs in North Carolina. Stroudsburg ( $\mathrm{Pa}$ ): Hutchinson Ross. 364 pp. \$25. Available from School of Forestry, Duke University, Durham, N. C. 27709. (This proceedings volume is for a conference partially funded by $N$. C. CEIP. It replaces the $N$. C. Peat Sourcebook in this publication list.)

8. McDonald, C. B. and A. M. Ash. Natural Areas Inventory of Tyrrell County, N. C. CEIP Report $\$$. October 1981. \$10.

9. Fusse1l, J., and E. J. Wilson. Natural Areas Inventory of Carteret County, N. C. CEIP Report $\$$. October 1981. \$10.

10. Nyfong, T. D. Natural Areas Inventory of Brunswick County, N. C. CEIP Report 非10. October 1981. \$10.

11. Leonard, S. W., and R. J. Davis. Natural Areas Inventory for'Pender County, N. C. CEIP Report 非1. October 1981. \$10.

12. Cribbins, Paul D., and Latta, R. Daniel. Coastal Energy Transportation Study: Alternative Technologies for Transporting and Handling Export Coal. CEIP Report 非2. January 1982. $\$ 10$.

13. Creveling, Kenneth. Beach Comunities and Oil Spills: Environmental and Economic Consequences for Brunswick County, N. C. CEIP Report \$13. May 1982. \$10. 
14. Rogers, Golden and Halpern, Inc., and Engineers for Energy and the Environment. The Design of a Planning Program to Help Mitigate Energy Facility-Related Air Quality Impacts in the Washington County, North Carolina Area. CEIP Report \#14. September 1982. \$10.

15. Fusse11, J., C. B. McDonald, and A. M. Ash. Natural Areas Inventory of Craven County, North Carolina. CEIP Report 非15. October 1982. $\$ 10$.

16. Frost, Cecil C. Natural Areas Inventory of Gates County, North Carolina. CEIP Report 非16. April 1982. \$10.

17. Stone, John R., Michael T. Stanley, and Paul T. Tschetter. Coastal Energy Transportation Study, Phase III, Volume 3: Impacts of Increased Rail Traffic on Communities in Eastern North Carolina. CEIP Report 非17. August 1982. \$10.

19. Pate, Preston P., and Jones, Robert. Effects of Upland Drainage on Estuarine Nursery Areas of Pamlico Sound, North Carolina. CEIP Report \#19. December 1981. \$1.00.

25. Wang Engineering Co., Inc. Analysis of the Impact of Coal Trains Moving Through Morehead City, North Carolina. CEIP Report 非25. October 1982. $\$ 10$.

26. Anderson \& Associates, Inc. Coal Train Movements Through the City of Wilmington, North Carolina. CEIP Report $\|_{2} 26$. October 1982. \$10.

27. Peacock, S. Lance and J. Merrill Lynch. Natural Areas Inventory of Mainland Dare County, North Carolina. CEIP Report 非7. November 1982. $\$ 10$.

28. Lynch, J. Merrill and S. Lance Peacock. Natural Areas Inventory of Hyde County, North Carolina. CEIP Report 非28. October 1982. \$10.

29. Peacock, S. Lance and J. Merrill Lynch. Natural Areas Inventory of Pamlico County, North Carolina. CEIP Report 非29. November 1982. \$10.

30. Lynch, J. Merrill and S, Lance Peacock. Natural Areas Inventory of Washington County, North Carolina. CEIP Report 非30. October 1982 . $\$ 10$.

31. Muga, Bruce J. Review and Evaluation of Oil Spill Models for Application to North Carolina Waters. CEIP Report 非1. August 1982. $\$ 10$.

33. Sorrel1, F. Yates and Richard R. Johnson. Oil and Gas Pipelines in Coastal North Carolina: Impacts and Routing Considerations. CEIP Report 非3. December 1982. \$10.

34. Roberts and Eichler Associates, Inc. Area Development Plan for Radio Island. CEIP Report \#34. June 1983. \$10.

35. Cribbins, Paul D. Coastal Energy Transportation Study, Phase III, Volume 4: The Potential for Wide-Beam, Shallow-Draft Ships to Serve Coal and Other Bulk Commodity Terminals along the Cape Fear River. CEIP Report \#35. August 1982. \$10. 


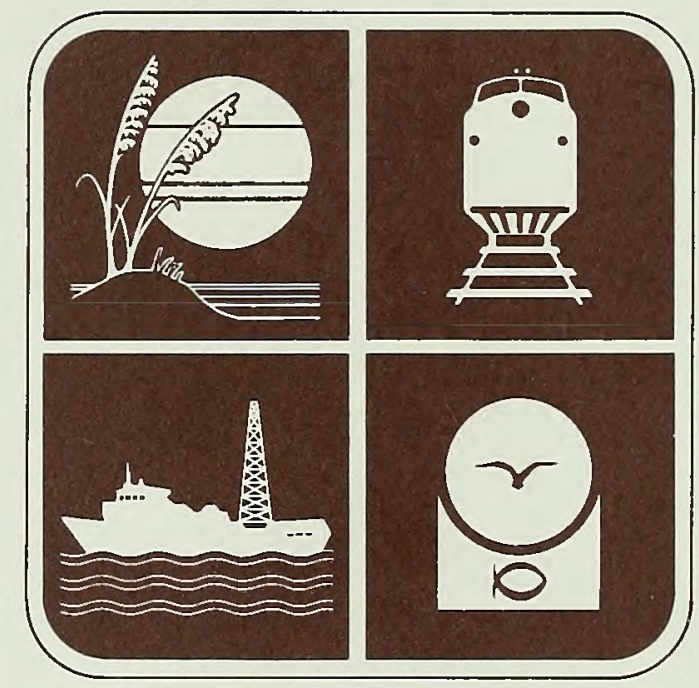

